\title{
Chemical characterization and source apportionment of size-segregated aerosol in the port-city of Venice (Italy)
}

\author{
Elena Gregoris ${ }^{\mathrm{a}, \mathrm{b}, *}$, Elisa Morabito ${ }^{\mathrm{b}}$, Elena Barbaro ${ }^{\mathrm{a}, \mathrm{b}}$, Matteo Feltracco ${ }^{\mathrm{b}}$, Giuseppa Toscano ${ }^{\mathrm{b}}$, \\ Eva Merico ${ }^{c}$, Fabio Massimo Grasso ${ }^{c}$, Daniela Cesari ${ }^{c}$, Marianna Conte ${ }^{c}$, Daniele Contini ${ }^{c}$, \\ Andrea Gambaro ${ }^{\mathrm{b}}$ \\ ${ }^{\text {a } I n s t i t u t e ~ o f ~ P o l a r ~ S c i e n c e s, ~ N a t i o n a l ~ R e s e a r c h ~ C o u n c i l ~ o f ~ I t a l y ~(I S P-C N R), ~ V i a ~ T o r i n o ~ 155, ~ V e n i c e, ~ M e s t r e, ~ I t a l y ~}$ \\ b Department of Environmental Science, Informatics and Statistics, Ca' Foscari University of Venice, Via Torino 155, Venice, Mestre, Italy \\ ${ }^{\mathrm{c}}$ Institute of Atmospheric Science and Climate, National Research Council of Italy (ISAC-CNR), Str. Prv. Lecce-Monteroni Km 1.2, 73100, Lecce, Italy
}

\section{A R T I C L E I N F O}

\section{Keywords:}

Size-segregated aerosol

Source apportionment

PMF

ship traffic

MOUDI

\section{Credit author statement}

E. Gregoris, Conceptualization, Formal analysis, Writing - original draft, Visualisation, Project administration. E. Morabito, Formal analysis, Investigation, Writing - original draft. E. Barbaro, Investigation, Writing - review \& editing. M. Feltracco, Investigation, Writing - review \& editing. G. Toscano, Resources. E. Merico, Investigation. F. M. Grasso, Investigation. D. Cesari, Investigation. M. Conte, Investigation. D. Contini, Project administration. A. Gambaro, Conceptualization, Supervision, Funding acquisition.

\section{Introduction}

Atmospheric particles interact with the clouds affecting climate (Rosenfeld et al., 2014) and have an important role in the deterioration of human health, causing allergy, asthma, cardiovascular, and respiratory diseases (Shiraiwa et al., 2012). The primary parameters determining the environmental and health effects of aerosol particles are their concentration, size, structure, and chemical composition (Pöschl, 2005). Among these characteristics, the particle size was identified as the most critical for human diseases, because the smaller the particles, the deeper they can penetrate the respiratory system: particles smaller than $2.5 \mu \mathrm{m}$ may reach the alveoli whereas ultrafine or nanoparticles $(<100 \mathrm{~nm})$, differently from fine particles, are small enough to pass from the pulmonary epithelium to the circulation. The systemic translocation of nanoparticles from the lung into the blood could cause more sever damages on human health, with respect to those caused by fine and coarse particles (Hoet et al., 2004). Moreover, fine particles tend to be suspended in air for long periods of time and can be transported for hundreds or thousands of km (Feltracco et al., 2020; Kim et al., 2015), enhancing their potential harmful effect in space and time.

Detailed information of aerosol sources is required to understand climate impacts and health effects of atmospheric aerosols, as well as to develop technologies and policies capable to mitigate air pollution in urbanized areas. This is particularly important for the city of Venice (Italy). The Venice Lagoon is the largest lagoon and one of the most important wetland sites in the Mediterranean Sea; it is a winter migration halt and breeding area for 200,000 birds (Martin, 2010). It is an example of an ecosystem that has been influenced by human interference for many years: a significant environmental risk is represented by the industrial area of Porto Marghera, one of the largest in Italy $(\sim 12$ $\mathrm{km}^{2}$ ), including chemical and metallurgical works, oil-refineries and

\footnotetext{
* Corresponding author. Via Torino 155, 30172, Venice, Mestre, Italy.

E-mail addresses: elena.gregoris@cnr.it, elena.gregoris@cnr.it (E. Gregoris), elisa.morabito@unive.it (E. Morabito), elena.barbaro@cnr.it (E. Barbaro), matteo.

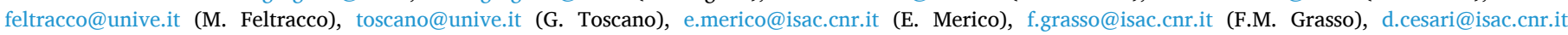
(D. Cesari), m.conte@isac.cnr.it (M. Conte), d.contini@isac.cnr.it (D. Contini), gambaro@unive.it (A. Gambaro).
} 
coal power plants (Masiol et al., 2010). Air quality is also affected by emissions of artistic glass-making factories on the island of Murano, by the presence of both commercial and industrial harbours, the urban area of Mestre, and road traffic (Gregoris et al., 2016; Rampazzo et al., 2008; Rossini et al., 2001). The Venice lagoon was designated as World Heritage Site in 1987 by Unesco and it is entitled Special Protection Area (SPA), as some of its sectors are Sites of Community Importance (SCI) and Important Bird Areas (IBA) (Corami et al., 2020).

In recent years, chemical characterization of aerosol in different size ranges has been progressively more studied, also by evaluating ten or twelve size ranges. In general, major ions are usually the main analysed class of chemicals, followed by carbonaceous species, such as organic and elemental carbon (Barbaro et al., 2019; Contini et al., 2014; Feltracco et al., 2018). Very few studies carried out a chemical characterisation of aerosol analysing trace metals alone or coupled with major ions (Bernardoni et al., 2017; Masiol et al., 2015; Taiwo et al., 2014). Many other studies characterised aerosol in a lower number of size ranges (Dordević et al., 2012;Đuričić-Milanković et al., 2018; Kumar et al., 2019; Paatero et al., 2017; Singh et al., 2016; Turšič et al., 2006). In Venice, size-segregated aerosol was previously analysed for trace metals by Masiol et al. (2015) and Toscano et al. (2011), for water soluble species by Barbaro et al. (2019), but only the latter work used a sampler able to extract nanoparticles from total aerosol.

One of the main challenging subjects addressed in this work is the assessment of the impact of maritime traffic to particulate matter. Previous studies evidenced that fine and ultrafine particles are more influenced by shipping emissions with respect to the coarse ones, especially during berthing periods (Viana et al., 2014). Other works confirmed that maritime traffic has a higher impact to particle number concentration, that is more influenced by smaller particles, with respect to mass concentration of $\mathrm{PM}_{2.5}$ (Contini et al., 2015; Donateo et al., 2014). Further investigation is mandatory to deeply understand these aspects. Viana et al. (2014) and Sorte et al. (2020) reviewed the recent studies focusing on the impact of maritime traffic to particulate matter, concluding the need of further studies to characterise the particle size distribution of aerosol emitted from ships, when reaching the coastal areas (Viana et al., 2014). In the reviewed papers, $\mathrm{PM}_{10}$ and $\mathrm{PM}_{2.5}$ are the most investigated particle fractions and only two publications included the calculation of the contribution to $\mathrm{PM}_{1}$ (Amato et al., 2009; Mazzei et al., 2008), while particles in the size ranges below $1 \mu \mathrm{m}$ have never been investigated using chemical tracers.

The aim of this work is to evaluate how the major sources of aerosol are impacting particles in different size in the area of Venice, specifically nanoparticles, for which little is known. To reach this objective we conducted a detailed chemical characterisation of aerosol collected in twelve different size ranges in Venice, using a MOUDI impactor (model 110). To our knowledge this is the first work in Europe evaluating simultaneously major ions, trace metals, and carbonaceous species in the same samples, in so much different aerosol size ranges and the first work detailing the size-dependent contribution of primary ship traffic to particles smaller than $1 \mu \mathrm{m}$ using chemical tracers. A detailed description of carbonaceous species concentration and size distribution was given in (Cesari et al., 2020), where a comparison between OC and EC results obtained in Venice and Rijeka (Croatia) is reported.

In the present paper, a preliminary discussion of the possible sources of aerosol was conducted comparing the size distribution of chemicals and investigating possible correlations among them. One of the most used methods for source apportionment is the Positive Matrix Factorisation (PMF) receptor model, which permits both the identification of the sources and the quantification of their contribution to airborne particulate. However, PMF is not always able to completely separate the sources from each other, as the identification of the sources is based on common tracers: for example, when using receptor models, shipping emissions generally appear mixed with other combustion sources (Viana et al., 2014). In order to overcome the disadvantages of the various methods for source apportionment, in this work the quantification of sources impacting on size-segregated aerosol was conducted in two ways: i) using approximate equations; ii) applying PMF separating collected data in two different datasets, one for coarse $(>1 \mu \mathrm{m})$ and the other for fine and ultrafine particles $(<1 \mu \mathrm{m})$, as previously done in Contini et al. (2014).

\section{Material and methods}

\subsection{Aerosol sampling}

Aerosol sampling was carried out at Sacca Fisola Island, Venice $\left(45^{\circ}\right.$ $25^{\prime} 42^{\prime \prime} \mathrm{N} ; 12^{\circ} 18^{\prime} 47^{\prime \prime}$ E) which is located along the Giudecca Canal, southeast of the historical centre (Figure S1). Venice and the surrounding areas are heavily affected by anthropogenic activities, such as industrial emissions from the Porto Marghera industrial area and traffic pollution from the nearby Mestre motorway. The sampling site is influenced by ship traffic (public transport, touristic, and merchant shipping), aircraft flying to the Venice Airport, and domestic heating (Stortini et al., 2009).

The sampling was conducted using a model 110 MOUDI cascade impactor, equipped with twelve impactor plates. Sampling of atmospheric particles undergoes several artefacts, both positive and negatives, including adsorption of organic vapour, nitrate volatilization, and retention of water vapour (Perrino et al., 2013; Vecchi et al., 2009; Wittmaack and Keck, 2004). Fujitani et al. (2006) verified that quartz fibre filter artefacts are minimal compared with aluminium foils or Teflon-membrane filter, thus we chose quartz fibre filters (QFFs, Whatman, UK) as substrate. Sixteen weekly samples were collected from August to November 2018 (Table S1). The sampler allows separate particles with different aerodynamic diameter. The inlet of the impactor has a nominal cut-off size of $18 \mu \mathrm{m}$, and the nominal cut-off sizes of the 10 stages are: $10,5.6,3.2,1.8,1.0,0.56,0.32,0.18,0.10$, and $0.056 \mu \mathrm{m}$. Finally, a back-up filter collected particles with aerodynamic diameter $<0.056 \mu \mathrm{m}$. Globally, the number of collected filters was 192 (sixteen sets of twelve filters). For every set of twelve sample filters, a field blank was taken by loading, carrying, and installing the QFF in the instrument with the air pump turned off, obtaining globally sixteen field blanks during the campaign. Analysis of blanks was carried out to evaluate eventual contamination and to calculate the method limits of detection (MDL) and quantification (MQL). MDL and MQL were evaluated as 3 and 10 times, respectively, the standard deviation of field blanks. Before the sampling, QFFs were decontaminated with a $4 \mathrm{~h}$ pre-combustion at $400{ }^{\circ} \mathrm{C}$ in a muffle furnace. After the gravimetric analysis, QFFs were cut and the single pieces underwent different treatments. A half of the filter was analysed for metals; a $1-\mathrm{cm}^{2}$ portion of the filter was analysed for elemental and organic carbon content and the remaining filter was analysed for ions.

\subsection{Aerosol analysis}

\subsubsection{Gravimetric analysis}

Gravimetric analysis was performed using a Sartorius CP225D balance (precision $\pm 0.01 \mathrm{mg}$ ), placed inside a clean room class 1000 , at Ca' Foscari University, Venice. Blanks and sampled QFFs were weighed three times over $24 \mathrm{~h}$, before and after the sampling, after a conditioning period of $48 \mathrm{~h}$. The balance and the filters were kept at humidity controlled ( $45 \pm 5 \%$ ) in a glove box, before and during the weighting procedure, in order to prevent errors in the weights due to the hygroscopy of the quartz filters. Relative standard deviation of the weights was always below $0.5 \%$. The average temperature was $22{ }^{\circ} \mathrm{C}$ ( \pm 2 standard deviation).

\subsubsection{Chemical analysis}

For the determination of ions and carboxylic acids, filters were extracted in ultrapure water into ultra-sonic bath and then filtrated through a $0.45 \mu \mathrm{m}$ PTFE filter. An ion chromatograph (IC, Thermo 
Scientific DionexTM ICS-5000, Waltham, MA, USA) coupled with a single quadrupole mass spectrometer (MS, MSQ PlusTM, Thermo Scientific, Bremen, Germany) was used to analyse anionic compounds: $\mathrm{Cl}^{-}$, $\mathrm{NO}_{3}^{-}, \mathrm{SO}_{4}^{2-}, \mathrm{Br}^{-}$, methanesulphonate (MSA), oxalate, malonate, succinate, malate, following the approach described elsewhere (Barbaro et al, 2017, 2019). The same IC instrumentation was also used to determine cationic species $\left(\mathrm{Na}^{+}, \mathrm{NH}_{4}^{+}, \mathrm{K}^{+}, \mathrm{Mg}^{2+}\right.$ ), using a capillary conductivity detector (Barbaro et al, 2017, 2019).

The determination of metals (Li, Ti, V, Cr, Mn, Fe, Co, Ni, Cu, Zn, Ga, $\mathrm{Ge}, \mathrm{Se}, \mathrm{Rb}, \mathrm{Sr}, \mathrm{Mo}, \mathrm{Cd}, \mathrm{Ba}, \mathrm{Pb}, \mathrm{U}$ ) in aerosol was carried out by mineralization of the half of each filter and subsequent instrumental analysis with ICP-MS (Inductively Coupled Plasma-Mass Spectrometry, iCAP RQ, Thermo Scientiphic). We used the methodology described in Stortini et al. (2009), with the following modifications: the mixture of reagents for the mineralization step was nitric acid, fluoridric acid, and hydrogen peroxide, with a ratio of $2: 1: 1$; the temperature program for microwave mineralization consisted in a heating up to $190{ }^{\circ} \mathrm{C}$ and a temperature maintenance for $15 \mathrm{~min}$. The calibration curves had $\mathrm{R}^{2}>0.999$. A standard reference material (NIST 1648a) was used to evaluate recoveries that ranged between $90 \%$ and $100 \%$.

Determinations of OC and EC were obtained applying a thermooptical transmittance (TOT) method for charring carbon correction using a Sunset laboratory carbon analyser (Sunset Laboratory Inc., OR, USA) with temperature offset correction. Punches of $1 \mathrm{~cm}^{2}$ were analysed according to the EUSAAR2 protocol, designed as the European standard procedure in the European Supersites for Atmospheric Aerosol Research. The procedure is described in (Cesari et al., 2020) and Merico et al. (2019a).

\subsection{Data elaboration}

\subsubsection{Coefficients and ratios}

In this work, the non-parametric Spearman coefficient ( $\rho$ ) was used to investigate the correlation among variables, since it is not link to the normal distribution of data; the correlation was considered significant when $\mathrm{p}<0.001$. The Mann-Whitney test was applied for comparing two sets of data of $\mathrm{PM}_{10}$ concentration (§3.1). It allows obtaining information about the statistical difference among samples and specifically to their provenience from the same data distribution or not, as a nonparametric alternative to the $t$-test.

The crustal enrichment factor $(\mathrm{EFc})$ has been used to evaluate the degree of pollution emitting sources in the aerosol. EFc assesses the enrichment of an element in the atmosphere by comparing its relative abundance (respect to a reference element) in atmosphere and in the upper crustal soil. EFc has been calculated for all analysed elements with the formula:

$E F c=(e l / r e f)_{\text {air }} /(e l / r e f)_{\text {crust }}$

where $e l$ and ref are the concentrations of the given element and the reference element, respectively, in air and in the upper crust, considering the average upper-crust geological concentrations reported in literature (Wedepohl, 1995). The reference is a typical crustal element, usually $\mathrm{Si}$, $\mathrm{Al}$, or $\mathrm{Fe}$. In this study, $\mathrm{Fe}$ has been chosen as reference element, in accordance with previous studies carried out in the same sampling area (Contini et al., 2012; Morabito et al., 2020) and in other polluted regions (Contini et al., 2010; Enamorado-Báez et al., 2015; Lyu et al., 2015; Malandrino et al., 2016; Rovelli et al., 2020).

If EFc value is close to 1, it shows a strong influence of the crustal component, EFc less than 10 indicates that crustal soils are the more probable source of the element, $10<\mathrm{EFc}<50$ indicates a contribution from non-crustal sources, while $\mathrm{EFc} \gg 100$ indicates an exceptionally enriched element.

\subsubsection{Estimation of sources contribution using formulae}

Sea salt aerosol (SSA) was estimated by the formula: SSA $=1.176$
$\left(\mathrm{Cl}^{-}(\mathrm{w} / \mathrm{v})+\mathrm{Na}^{+}(\mathrm{w} / \mathrm{v})\right)$ (Perrino et al., 2009). Secondary inorganic aerosol (SIA) is the sum of non-sea salt $\mathrm{SO}_{4}^{2-}\left(\right.$ nss- $\left.\mathrm{SO}_{4}^{2-}\right), \mathrm{NO}_{3}^{-}$and $\mathrm{NH}_{4}^{+}$ mass concentration (Perrino et al., 2009). Mineral dust (MD) and trace element oxides (TEO) were estimated by using adapted formulas by Dabek-Zlotorzynska et al. (2019). MD was calculated as $2.42 \mathrm{Fe}(\mathrm{w} / \mathrm{v})+$ $1.94 \mathrm{Ti}(\mathrm{w} / \mathrm{v})$. The original formula also included a contribution by $\mathrm{Si}$, $\mathrm{Ca}$ and $\mathrm{K}$, not evaluated in this work, thus the contribution of MD can be underestimated. TEO was calculated using the following formula: TEO $=1.47 \mathrm{~V}(\mathrm{w} / \mathrm{v})+1.29 \mathrm{Mn}(\mathrm{w} / \mathrm{v})+1.27 \mathrm{Ni}(\mathrm{w} / \mathrm{v})+1.25 \mathrm{Cu}(\mathrm{w} / \mathrm{v})+$ $1.24 \mathrm{Zn}(\mathrm{w} / \mathrm{v})+1.32 \mathrm{As}(\mathrm{w} / \mathrm{v})+1.08 \mathrm{~Pb}(\mathrm{w} / \mathrm{v})+1.2 \mathrm{Se}(\mathrm{w} / \mathrm{v})+1.37 \mathrm{Sr}$ $(\mathrm{w} / \mathrm{v})+1.31 \mathrm{Cr}(\mathrm{w} / \mathrm{v})$.

Elemental carbon, originated directly from combustion emissions, was considered to constitute the Primary Anthropogenic Aerosol (PAA). For taking into account organic compounds condensing from the exhaust gases onto the elemental carbon particles, the primary organic carbon $\left(\right.$ OC $_{\text {prim }}$ ) was estimated as 1.1 x EC (Castro et al., 1999); OC $_{\text {prim }}$ was then multiplied by a conversion factor which estimates the average organic molecular weight per carbon weight of the measured aerosol. This factor may assume various values depending on the aerosol composition and the location of the sampling site (Perrino et al., 2009). Turpin and Lim (2001) suggested the use of 2.1 and 1.6, as conversion factors for non-urban and urban aerosol, respectively. Sacca Fisola is considered a background station in an urban area, thus we decided to use the factor 1.8, as already done in Perrino et al. (2009). The same conversion factor was used to evaluate the primary organic matter $\left(\mathrm{OM}_{\text {prim }}\right)$ and the organic aerosol (OA) contribution, mostly of secondary origin, starting from the non-primary organic carbon. The used formulas are summarised as follows:

$$
\begin{aligned}
& \mathrm{PAA}=\mathrm{EC}+\mathrm{OM}_{\text {prim }}=\mathrm{EC}+1.8 \times \mathrm{OC}_{\text {prim }}=\mathrm{EC}+1.8 \times 1.1 \times \mathrm{EC} \\
& \mathrm{OA}=1.8 \times\left(\mathrm{OC}-\mathrm{OC}_{\text {prim }}\right)=1.8 \times(\mathrm{OC}-1.1 \times \mathrm{EC})
\end{aligned}
$$

In addition to be above mentioned sources, the contribution of ship traffic to size-segregated aerosol was estimated. Various chemicals were identified as possible markers of shipping emissions ( $\mathrm{V}$ and $\mathrm{Ni}$ above all, but also $\mathrm{Th}, \mathrm{Pb}, \mathrm{Zn}, \mathrm{SO}_{4}^{2-}$ ) and usually tracer ratios are preferred for the identification of this kind of pollution source, when associated to modelling approaches (Viana et al., 2014), as will be done afterwards (§3.3.3). On the other hand, the calculation of tracer ratios alone does not permit a numerical quantification of the contribution of shipping to particulate matter and vanadium has been identified as the best tracer for indicating shipping emission (Mamoudou et al., 2018; Zhao et al., 2013). Thus, the primary contribution of ship traffic $\mathrm{PM}_{\text {ship }}$ was extracted considering only vanadium as a marker for the combustion in ships' engines, following the approach first introduced by Agrawal et al. (2009):

$$
P M_{\text {ship }}=\frac{R \cdot V}{F_{V, H F O}}
$$

where HFO stands for Heavy Fuel Oil; V is the in-situ ambient concentration of vanadium ( $\mathrm{ng} \mathrm{m}^{-3}$ ); $\mathrm{F}_{\mathrm{V}, \mathrm{HFO}}$ is the typical $\mathrm{V}$ content (ppm) in HFOs used by vessels; in the absence of chemical analyses of fuel, the value of $65 \pm 25 \mathrm{ppm}$ was used to cover the typical range of $\mathrm{F}_{\mathrm{V}, \mathrm{HFO}}$ (Cesari et al., 2014; Gregoris et al., 2016); $\mathrm{R}$ is the average ratio of $\mathrm{PM}_{2.5}$ to normalized V emitted (ppm) and was estimated at $8205.8 \mathrm{ppm}$, for locations with HFO-burning ship emissions. Although this coefficient refers to $\mathrm{PM}_{2.5}$, we used it as reference value for the assessment of the contribution of all size ranges, for comparison reasons. Thus, the calculated contribution should be considered as an approximation in its absolute value.

The contributions of the various sources were calculated sample by sample; the relative contribution (\%) was extracted dividing the absolute contribution (in concentration unit) for the collected mass of the corresponding sample. For estimating the relative contribution of sources referred to fractions (total suspended, coarse, fine, and ultrafine 
particles) and not to single stages, the sum of the contributions of all the stages included in the fraction was divided by the sum of the collected aerosol mass in the stages corresponding to that fraction. The same approach was adopted in the estimation of the relative contributions obtained by PMF.

\subsubsection{Positive matrix factorisation}

Data were refined in order to obtain more robust datasets. Variables with more than $50 \%$ of values under the detection limit (DL) were rejected. Values under DL were substituted by half of DL. As uncertainty, the standard deviations of the method, normalized for the average sampling volumes of each campaign, were used for metals and ions; the uncertainty of values under DL was 5/6 DL. Uncertainties on carbon were determined accordingly to Merico et al. (2019b). Outliers have been identified based on the quartile method. A discrimination between "strong", "weak", and "bad" variables has been made, according to the signal to noise $(\mathrm{S} / \mathrm{N})$ ratio criterion, the residual analysis and evaluating the observed/predicted scatter plots. PM was always labelled as "total variable" and therefore categorized as "weak", following the approach reported in Gregoris et al. (2016). The stability of the solution and the uncertainty associated to the results were estimated using the Bootstrap (BS) error estimation; rotational ambiguity was explored using the displacement (DISP) error estimation. In order to individuate the right number of factors, different solutions were explored and the most reasonable solution was selected based on the parameters IM (maximum of the average of the scaled residual) and IS (maximum of the standard deviation of the scaled residuals), together with the $Q$ value (goodness of the fit), following the approach reported in Contini et al. (2012).

\section{Results and discussion}

\subsection{Size distribution of aerosol}

From August to November 2018, weekly values of total aerosol concentration, calculated as the sum of all stages, ranged from $19 \mu \mathrm{g}$ $\mathrm{m}^{-3}$ to $51 \mu \mathrm{g} \mathrm{m}^{-3}$, with a median of $34 \mu \mathrm{g} \mathrm{m}^{-3}$. Particulate matter in Sacca Fisola was mainly composed of coarse particles (65\% of total suspended particulate) and fine particles (33\%); nanoparticles represented $2 \%$ of total suspended particulate (Figure S2). The median $\mathrm{PM}_{10}$ concentration, calculated as sum of stages with particle diameters $<10$ $\mu \mathrm{m}$, was $30 \mu \mathrm{g} \mathrm{m}^{-3}$ (IQR: 23-33). No significant difference (p-val$\mathrm{ue}<0.001)$ was obtained by comparing with median value $\left(30 \mu \mathrm{g} \mathrm{m}^{-3}\right.$, IQR: 25-38) obtained by the Regional Agency of Environmental Prevention and Protection of Veneto (ARPAV), in the same site and period. $\mathrm{PM}_{10}$ concentration measured in this work was similar or slightly lower with respect to that previously recorded in the same area (Contini et al., 2012; Gregoris et al., 2016), higher with respect of that reported by Sulejmanović et al. (2014) in the urban area of Sarajevo (Bosnia and Herzegovina); it was much lower with that measured in New Delhi (India) by Kumar et al. (2018) and in Chinese cities along the western Pacific coast (Xu et al., 2015).

The median size distribution of particulate matter (Fig. 1) showed the typical bimodal shape (Canepari et al., 2019; Contini et al., 2014; Sun et al., 2013), with peaks of concentration around $6 \mu \mathrm{g} \mathrm{m}^{-3}$ in the range $10-3.2 \mu \mathrm{m}$ and of $4.3 \mu \mathrm{g} \mathrm{m}^{-3}$ at $1.0-0.56 \mu \mathrm{m}$ (Table S2). Fig. 1 shows a comparison of the size distribution in August and November. Both distributions were bimodal, but it is evident a seasonal difference, consisting in a prevalence of the fine fraction (in $\Delta c / \Delta \log D_{p}$ ), with maximum concentrations in the size range $1.0-0.56 \mu \mathrm{m}$, with respect to the coarse one (10-3.2 $\mu \mathrm{m})$ in the cold period; the opposite was observed in August, when a peak of concentration in the coarse fraction, higher with respect to that measured in November. The same trend has been observed in another city located in the Po Valley by Canepari et al. (2019).

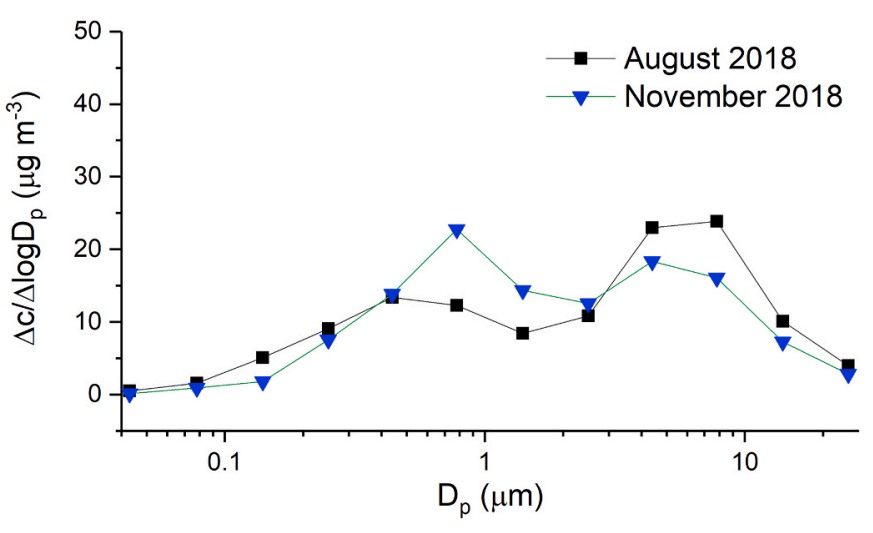

Fig. 1. Aerosol size distribution in August and November 2018.

\subsection{Chemical composition of aerosol}

Total suspended particulate (TSP) was composed of various classes of chemicals. The sum of all analysed chemicals represented $41 \%$ of TSP. Specifically, $30 \%$ of TSP was composed of ionic species, $9 \%$ was carbonaceous species, and $2 \%$ was trace metals. The most represented species was $\mathrm{SO}_{4}^{2-}$ ( $9 \%$ of TSP), followed by $\mathrm{NO}_{3}^{-}$and $\mathrm{OC}(8 \%), \mathrm{Cl}^{-}(6 \%)$, and $\mathrm{Na}^{+}(4 \%)$, coherently with previous works (Barbaro et al., 2019; Contini et al., 2012; Gregoris et al., 2016; Stortini et al., 2009), although some of these works referred to $\mathrm{PM}_{10}$ or $\mathrm{PM}_{2.5}$ concentration. Among the analysed metals, the most present were $\mathrm{Fe}(66 \%$ of total metals) and $\mathrm{Ti}$ $(8 \%)$. The concentration of the most elements was in accordance with values found in other studies regarding size segregated aerosol in continental (Jiang et al., 2015) and coastal cities (Ar1 et al., 2020; Martins et al., 2020). The average concentrations of elements as $\mathrm{Fe}, \mathrm{Co}, \mathrm{Cu}, \mathrm{Zn}$, and $\mathrm{Pb}$, considerably lower than that found in the above mentioned works, are in accordance with a study carried out in a port-city (Contini et al., 2010) and in other previous works carried out in the same area (Contini et al, 2011, 2012; Masiol et al, 2010, 2012a, 2012b; Morabito et al., 2020). The relative concentration of carbon was lower than that reported by Merico et al. (2019a) in Lecce (Italy), similar to that measured by Wang et al. (2015) in China. The remaining part of TSP could be mineral dust, mainly constituted of oxides of various metals and organic matter, including soluble and insoluble organic compounds not analysed in this work (Bressi et al., 2013; Sciare et al., 2005; Yan et al., 2012). Additionally, some losses of chemicals are possible using a cascade impactor, thus the concentration of some chemicals could be underestimated. As an example, in a previous work by Contini et al. (2014), the loss of $\mathrm{NO}_{3}^{-}$and $\mathrm{SO}_{4}^{2-}$ was estimated as $35 \%$ and $19 \%$ respectively, comparing MOUDI with a $\mathrm{PM}_{10}$ sampler.

Ionic species represented a relevant percentage of particulate matter in all collected size ranges, with the exception of the size $<0.056 \mu \mathrm{m}$, where they contributed for only $3 \%$ of aerosol mass. Trace metals represented from 1 to $6 \%$ of particulate mass, being maximum in the range $0.10-0.056 \mu \mathrm{m}$. Carbonaceous species showed an increased concentration with decreasing particle size, reaching the maximum contribution of $43 \%$ to particle mass in the size range $0.10-0.056 \mu \mathrm{m}$. Globally, particles of the coarse fraction were mainly constituted of ions, with a little contribution of metal and carbon; moving towards fine and ultrafine particles, ions were gradually substituted by carbonaceous species. The unexplained percentage of total mass was significant in all collected size ranges. More details about the concentration of ions and metals and their size distribution are reported in the Supplementary Material. A deep description of OC and EC trend in these samples and of their size distribution was given in (Cesari et al., 2020). 


\subsection{Source identification and apportionment}

\subsubsection{Source identification using coefficients}

In this study, $\mathrm{Cl}^{-}$was almost completely distributed in the coarse fraction, because the predominant source is sea salt, as suggested by the significant correlation between $\mathrm{Cl}^{-}$and $\mathrm{Na}^{+}(\rho=0.83, \mathrm{p}<0.001)$. Other sources of $\mathrm{Cl}^{-}$, such as waste incineration and secondary aerosol formation, are less probable, since they usually produce $\mathrm{Cl}^{-}$in the fine fraction (Kaneyasu et al., 1999). The $\mathrm{Cl}^{-} / \mathrm{Na}^{+}$ratio was calculable only for the coarse fraction, due to the $\mathrm{Na}^{+}$concentration below MQL in the fine and ultrafine fractions. Median $\mathrm{Cl}^{-} / \mathrm{Na}^{+}$ratio was $1.64 \mathrm{w} / \mathrm{w}$ (range $0.68-6.96$ ), similar to the expected value in sea water of 1.81 (McInnes et al., 1994); the calculated median $\mathrm{Cl}^{-}$depletion for the coarse fraction was $9.5 \%$. This means that the coarse marine aerosol was just emitted, contrary to what previously observed in an urban area of Venice (Barbaro et al., 2019). This difference can be explained by the very closeness of the sampling site to the sea (Adriatic sea, Figure S1): it was observed that at coastal locations the coarse fraction is dominated by fresh emissions of sea salt (Herner et al., 2006) and that the mass ratio of $\mathrm{Cl}^{-} / \mathrm{Na}^{+}$has a tendency to decrease as the distance from the sea increases (Li et al., 2016).

The sources of $\mathrm{SO}_{4}^{2-}$ could be various, including both natural and anthropogenic origin. The marine contribution to the $\mathrm{SO}_{4}^{2-}$ concentration was distinguished from the other sources, using the typical ratio of $\mathrm{SO}_{4}^{2-} / \mathrm{Na}^{+}$in the sea $(0.25 \mathrm{w} / \mathrm{w})$. nss-SO ${ }_{4}^{2-}$, obtained as follows: nss- $\mathrm{SO}_{4}^{2-}$ $=\mathrm{SO}_{4}^{2-}-0.25 \mathrm{Na}^{+}$(Prodi et al., 2009), represented $93 \%$ of total $\mathrm{SO}_{4}^{2-}$, on average. nss- $\mathrm{SO}_{4}^{2-}$ size distribution was similar to that observed for MSA and a significant correlation was found between the two anionic species $(\rho=0.83, \mathrm{p}<0.001)$. These results suggest a possible marine biogenic origin for nss-SO ${ }_{4}^{2-}$ (Gondwe et al., 2003). MSA to nss-SO ${ }_{4}^{2-}$ ratio permits to disentangle marine biogenic emission from other sulphur sources. The ratio found in this work varied between 0.002 and $0.03 \mathrm{w} / \mathrm{w}$, with a median value of $0.01 \mathrm{w} / \mathrm{w}$, lower than that observed by Barbaro et al. (2019) in Venice in March-April 2016and than the typical range found in the unpolluted mid-latitudes (0.06-0.12 w/w, Chen et al., 2012). A low MSA/nss-SO ${ }_{4}^{2-}$ could be due to an additional anthropogenic source of nss-SO $\mathrm{SO}_{4}^{2-}$. The significant correlation between nss-SO ${ }_{4}^{2-}$ and V $(\rho=0.51, \mathrm{p}$ $<0.001$ ), typical tracer of ship emissions (Viana et al., 2014) and the similar size distribution between the two variables, mainly distributed in the fine fraction, suggest that, among the various sources, also ship traffic could give a contribution to the concentration of $\mathrm{SO}_{4}^{2-}$ in aerosol, as reported by Healy et al. (2010) and Popovicheva et al. (2009).

The formation of $\mathrm{NO}_{3}^{-}$in the fine mode can be due to in-cloud processes and gas-to-particle condensation of its precursors onto preexisting particles (Barbaro et al., 2019). In the coarse mode it could generally be originated in high sea salt concentration environment, reacting with $\mathrm{NaCl}$ and generating $\mathrm{HCl}$, with a consequent $\mathrm{Cl}^{-}$depletion (Contini et al., 2014). In this work, little reduction in the foreseen $\mathrm{Cl}^{-}$ concentration from sea salt was observed, compared to that previously measured in the urban area of Venice (Barbaro et al., 2019). This is coherent with the size distribution of $\mathrm{NO}_{3}^{-}$in the two sites: in that previous work, the $\mathrm{NO}_{3}^{-}$concentration, expressed as $\Delta \mathrm{c} / \Delta \log \mathrm{D}_{\mathrm{p}}$, was mainly distributed in the coarse fraction. On the contrary, results obtained from Sacca Fisola Island showed a distribution shifted towards the fine fraction, confirming a relevant difference in the contribution of the various sources of $\mathrm{NO}_{3}^{-}$between the two areas.

$\mathrm{NH}_{4}^{+}$showed a bimodal distribution, with contributions in the coarse and in the ultrafine fractions. In aerosol it could be present in form of $\left(\mathrm{NH}_{4}\right)_{2} \mathrm{SO}_{4}\left(\rho_{\mathrm{NH} 4+/ \mathrm{SO}} 42-=0.73, \mathrm{p}<0.001\right)$. Results showed an excess of $\mathrm{NH}_{4}^{+}$with respect to the concentration necessary to neutralise $\mathrm{SO}_{4}^{2-}$ (Figure S7), with the possible formation of secondary $\mathrm{NH}_{4} \mathrm{NO}_{3}\left(\rho_{\mathrm{NH} 4+}\right.$ / NO3- $=0.42, \mathrm{p}<0.001)$. $\mathrm{NO}_{3}^{-}$could also be present in form of $\mathrm{KNO}_{3}$; this possibility is confirmed by the significant correlation between $\mathrm{K}^{+}$and $\mathrm{NO}_{3}^{-}(\rho=0.53)$.

$\mathrm{K}^{+}$showed a complex distribution; its presence in aerosol can be due to different sources, such as marine spray, soil-derived particles, biomass combustion and industry (Pachon et al., 2013). 84\% of $\mathrm{K}^{+}$was non-sea salt $\mathrm{K}^{+}$(nss- $\mathrm{K}^{+}$), calculated as nss- $\mathrm{K}^{+}=\mathrm{K}^{+}-0.0355 \mathrm{Na}^{+}$(Morales et al., 1998). Coherently, the $\mathrm{K}^{+} / \mathrm{Na}^{+}$ratio in aerosol samples (average: $0.060 \mathrm{w} / \mathrm{w}$; range: $0.030-0.441 \mathrm{w} / \mathrm{w}$ ) was higher than the $\mathrm{K}^{+} / \mathrm{Na}^{+}$ratio in sea water $(0.036 \mathrm{w} / \mathrm{w})$. This evidence conducts to hypothesize that sea salt only partially contributed to the concentration of $\mathrm{K}^{+}$and that other predominant sources were also present.

To investigate the potential sources of carboxylic acids, the relationship between malonate and succinate was analysed, as an indicator of the intensity of the photochemical production of dicarboxylic acids (Barbaro et al., 2019). Succinic acid $\left(\mathrm{C}_{4}\right)$ can be degraded to malonic acid $\left(\mathrm{C}_{3}\right)$ through decarboxylation reactions activated by radical groups -OH (Kawanaka et al., 2004). The median value of $\mathrm{C}_{3} / \mathrm{C}_{4}$ in TSP was $3.96(1.8-19) \mathrm{w} / \mathrm{w}$. Samples collected in the weeks 2-9 October and 30 October-7 November showed a $\mathrm{C}_{3} / \mathrm{C}_{4}$ above $10 \mathrm{w} / \mathrm{w}$ in TSP, suggesting the presence of aged aerosol while in the other samples the $C_{3} / C_{4}$ ratio was always between 2 and $7 \mathrm{w} / \mathrm{w}$.

The crustal enrichment factors of metals were calculated discriminating the size of the particles (coarse and fine + ultrafine) (Figure S9). In the coarse fraction many elements have a strong influence of the crustal component: $\mathrm{Rb}, \mathrm{Ti}, \mathrm{Sr}, \mathrm{Co}, \mathrm{Ba}(\mathrm{EFc} \approx 1$ ), and $\mathrm{Mn}, \mathrm{Ga}, \mathrm{U}, \mathrm{V}, \mathrm{Li}$ $(\mathrm{EFc} \approx 2) . \mathrm{Cr}, \mathrm{Ni}$, and $\mathrm{Pb}$ have $\mathrm{EFc}$ close to 10 , indicating that the crustal source is the more probable source of the elements. For $\mathrm{Zn}, \mathrm{Cu}, \mathrm{Ge}$, and $\mathrm{Cd}$ is more evident the contribution from anthropogenic sources. Se and Mo, with EFc 100 are exceptionally enriched. For all elements, excepting $\mathrm{Cu}, \mathrm{EFcs}$ in the fine fractions are higher than the

Table 1

Average contribution of the investigated sources to size-segregated aerosol.

\begin{tabular}{|c|c|c|c|c|c|c|c|}
\hline & $\begin{array}{l}\text { SSA } \\
\mu \mathrm{g} \mathrm{m}^{-3}(\%)\end{array}$ & $\begin{array}{l}\text { SIA } \\
\mu \mathrm{g} \mathrm{m}^{-3}(\%)\end{array}$ & MD ng m ${ }^{-3}(\%)$ & TEO ng $\mathrm{m}^{-3}(\%)$ & PPA ng m ${ }^{-3}(\%)$ & $\begin{array}{l}\mathrm{OA} \\
\mu \mathrm{g} \mathrm{m}^{-3}(\%)\end{array}$ & Ship traffic $\mathrm{ng} \mathrm{m}^{-3}(\%)$ \\
\hline$>18 \mu \mathrm{m}$ & $0.38(26 \%)$ & $0.22(14 \%)$ & $58(3.8 \%)$ & $5.5(0.4 \%)$ & $1.0(<0.1 \%)$ & $0.05(3.0 \%)$ & $9.2(0.6 \%)$ \\
\hline $18-10 \mu \mathrm{m}$ & $0.76(29 \%)$ & $0.23(8.7 \%)$ & $83(3.4 \%)$ & $7.4(0.3 \%)$ & $2.2(0.1 \%)$ & $0.18(6.5 \%)$ & $14.2(0.6 \%)$ \\
\hline $10-5.6 \mu \mathrm{m}$ & $1.6(31 \%)$ & $0.49(9.0 \%)$ & $166(3.2 \%)$ & $11(0.3 \%)$ & $5.9(0.2 \%)$ & $0.46(8.6 \%)$ & $29.5(0.6 \%)$ \\
\hline $5.6-3.2 \mu \mathrm{m}$ & $0.79(14 \%)$ & $0.62(12 \%)$ & $282(5.4 \%)$ & $18(0.4 \%)$ & $21(0.4 \%)$ & $0.63(12 \%)$ & $33.3(0.6 \%)$ \\
\hline $3.2-1.8 \mu \mathrm{m}$ & $0.15(5.2 \%)$ & $0.64(21 \%)$ & $157(5.5 \%)$ & $14(0.4 \%)$ & $40(1.5 \%)$ & $0.31(11 \%)$ & $20.3(0.7 \%)$ \\
\hline $1.8-1.0 \mu \mathrm{m}$ & $0.04(0.93 \%)$ & $1.8(37 \%)$ & $87(2.9 \%)$ & $17(0.5 \%)$ & $180(5.0 \%)$ & $0.59(17 \%)$ & $43.3(1.2 \%)$ \\
\hline $1.0-0.56 \mu \mathrm{m}$ & $0.03(0.66 \%)$ & $2.0(36 \%)$ & $63(1.6 \%)$ & $17(0.4 \%)$ & $208(4.5 \%)$ & $0.96(20 \%)$ & $59.9(1.3 \%)$ \\
\hline $0.56-0.32 \mu \mathrm{m}$ & $<0.01(0.14 \%)$ & $1.0(32 \%)$ & $33(1.2 \%)$ & $12(0.4 \%)$ & $228(8.1 \%)$ & $0.86(27 \%)$ & $72.2(2.4 \%)$ \\
\hline $0.32-0.18 \mu \mathrm{m}$ & $<0.01(0.11 \%)$ & $0.48(22 \%)$ & $25(1.3 \%)$ & $9.3(0.5 \%)$ & $216(12 \%)$ & $0.48(23 \%)$ & $77.0(3.8 \%)$ \\
\hline $0.18-0.10 \mu \mathrm{m}$ & - & $0.15(16 \%)$ & $19(3.9 \%)$ & $5.1(1.0 \%)$ & $146(21 \%)$ & $0.28(35 \%)$ & $43.2(5.3 \%)$ \\
\hline $0.10-0.056 \mu \mathrm{m}$ & $0.02(4.1 \%)$ & $0.03(12 \%)$ & $23(6.6 \%)$ & $4.5(1.6 \%)$ & $88(37 \%)$ & $0.10(39 \%)$ & $27.9(13 \%)$ \\
\hline$<0.056 \mu \mathrm{m}$ & - & $0.02(6.4 \%)$ & $22(4.5 \%)$ & $4.2(1.0 \%)$ & $81(19 \%)$ & $0.06(14 \%)$ & $13.4(4.7 \%)$ \\
\hline Coarse fraction & 3.7 (18\%) & $3.8(17 \%)$ & $834(4.3 \%)$ & $73(0.4 \%)$ & $232(1.1 \%)$ & $2.1(10 \%)$ & $140(0.7 \%)$ \\
\hline Fine fraction & $0.04(0.3 \%)$ & $3.4(30 \%)$ & $140(1.4 \%)$ & $43(0.4 \%)$ & $749(7.4 \%)$ & $2.4(22 \%)$ & $229(2.6 \%)$ \\
\hline Ultrafine fraction & $0.01(1.0 \%)$ & $0.04(8.1 \%)$ & $45(7.4 \%)$ & $8.7(1.6 \%)$ & $131(23 \%)$ & $0.13(19 \%)$ & $0.03(7.0 \%)$ \\
\hline TSP & $3.8(12 \%)$ & $7.2(21 \%)$ & $1019(3.3 \%)$ & $124(0.4 \%)$ & $1096(3.4 \%)$ & $4.6(14 \%)$ & $390(1.2 \%)$ \\
\hline
\end{tabular}


corresponding EFcs in the coarse one. Given that high EFcs are related to anthropogenic activities, this result confirms that the fine mode is more influenced by anthropogenic activities, with respect to the coarse mode.

\subsubsection{Source apportionment by approximate formulas}

Assuming that all $\mathrm{Na}^{+}$and $\mathrm{Cl}^{-}$have exclusively marine origin, the contribution of SSA was calculated, as reported in paragraph 2.3.2. SSA contributed on average for $12 \%$ to total suspended particulate, with a distribution over the sampling period from $2.6 \%$ to $23 \%$. The size distribution of SSA showed the maximum of $30 \%$, on average, for particles of size $18-10 \mu \mathrm{m}$ and $10-5.6 \mu \mathrm{m}$ ns-SO $\mathrm{SO}_{4}^{2-}, \mathrm{NO}_{3}^{-}$, and $\mathrm{NH}_{4}^{+}$(SIA) contributed for $22 \%$ (range $12-40 \%$ ) to total suspended particulate, on average, reaching a contribution of $37 \%(16-67 \%)$ in the dimensional range $1.8-0.56 \mu \mathrm{m}$. MD and TEO contributed on average for $3.3 \%$ (range $1.7-7.5 \%)$ and $0.4 \%(0.2-1.2 \%)$ to total suspended particulate, respectively. The MD size distribution was bimodal, with a mode in the coarse fraction (1.8-5.6 $\mu \mathrm{m})$ and a second one in the nano fraction $(<0.1 \mu \mathrm{m})$, whereas TEO was characterised by an incremental contribution with particle decreasing, with a peak of $1.6 \%$ in the range $0.1-0.056 \mu \mathrm{m}$. In TSP, PAA ranged from $1.1 \%$ to $5.0 \%$, with an average of $3.4 \%$, comparable to that calculated by Perrino et al. (2009) in the background stations. No specific chronological trend was observed. The PAA contribution rise with decreasing particle size, reaching the maximum value of $37 \%$, on average, at size $0.10-0.056 \mu \mathrm{m}$, coherent with the combustion processes emitting in the finer fractions of aerosols (Cesari et al., 2020). The average contribution of OA to total suspended particulate was $14 \%$ (range 9-27\%), comparable to a previous work (Perrino et al., 2009). No specific chronological trend was observed. The OA contribution rose with size particle decreasing, reaching the maximum value of $39 \%$, on average, at size $0.10-0.056 \mu \mathrm{m}$.

In Table 1 and Fig. 2, average contributions of SSA, SIA, MD, TEO, $\mathrm{PAA}$, and $\mathrm{OA}$ are summarised and shown, whereas the contributions in each sample is reported in the Supplementary Material (Figure S10). It is evident that SSA was produced almost exclusively in the coarse fraction. The fine fraction was dominated by SIA ( $30 \%$ of contribution) and OA (22\%), with an increase in the contribution of PAA (7\%), with respect to the coarse fraction (1\%). PAA increased as particle dimension decreased, being maximum in nanoparticles ( $23 \%$ of contribution to particle mass). Nanoparticles were also characterized by a relevant contribution of OA (19) and lower, but significant contributions of SIA (8\%) and MD (7\%).

The contribution of ship traffic was estimated separately from the other sources, since shipping emissions could include also part of PPA and TEO. In TSP, $\mathrm{PM}_{\text {ship }}$ ranged from $0.2 \%$ to $2.1 \%$, with an average of $1.2 \%$. The average $\mathrm{PM}_{\text {ship }}$ was below $1 \%$ for particles $>1.8 \mu \mathrm{m}$ and rapidly increased for smaller particles, reaching an average of $13 \%$ for particles between $0.10 \mu \mathrm{m}$ and $0.056 \mu \mathrm{m}$ (Fig. 3). The contribution of $\mathrm{PM}_{\text {ship }}$ to $\mathrm{PM}_{10}$ calculated from 2018 data (1.4\%) was a bit lower with respect to that previously observed in Venice with the same approach, within the POSEIDON project (Interreg MED, 2007-2013), in the period 2009-2013 (Gregoris et al., 2016). The comparison between the results of POSEIDON and ECOMOBILITY projects is shown in the Supplementary Information (Figure S11). In a recently published work, the

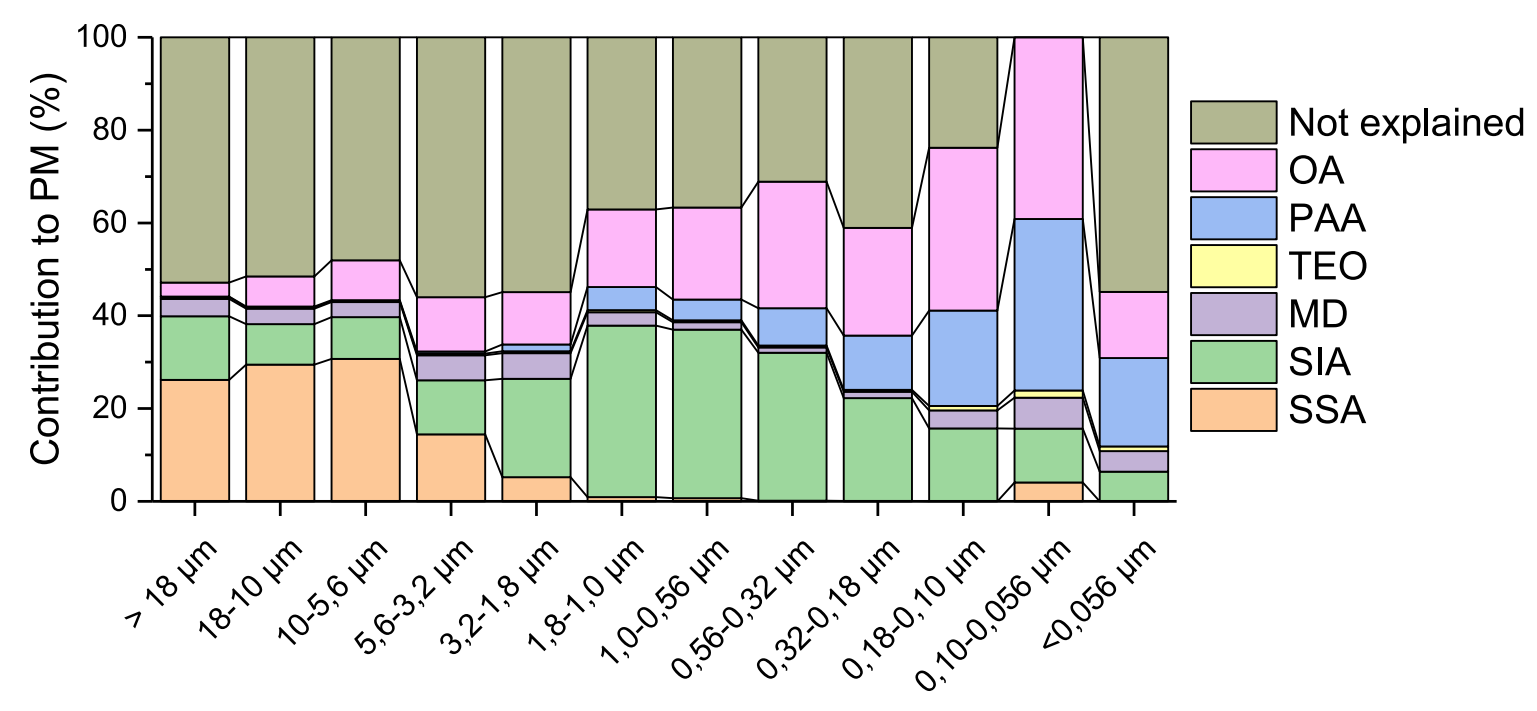

Coarse fraction

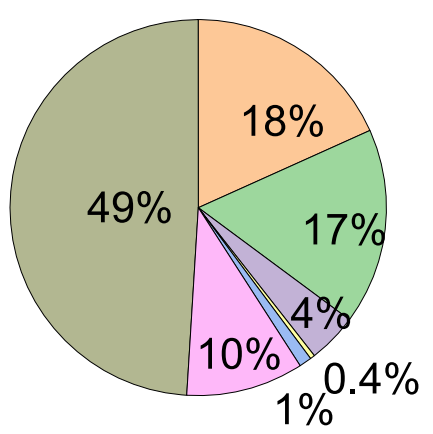

Fine fraction

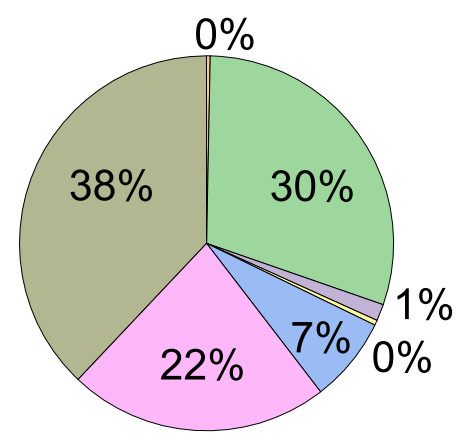

Ultrafine fraction

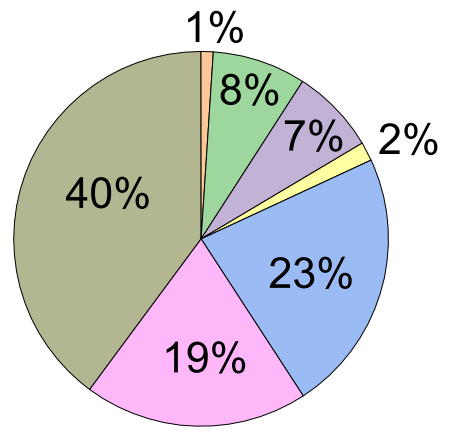

SSA SIA MD TEO PAA OA Not exp

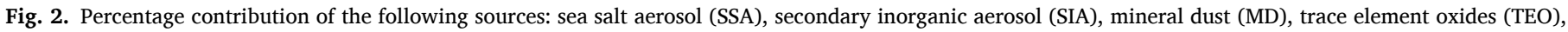
primary anthropogenic aerosol (PAA), and OA (organic aerosol). 


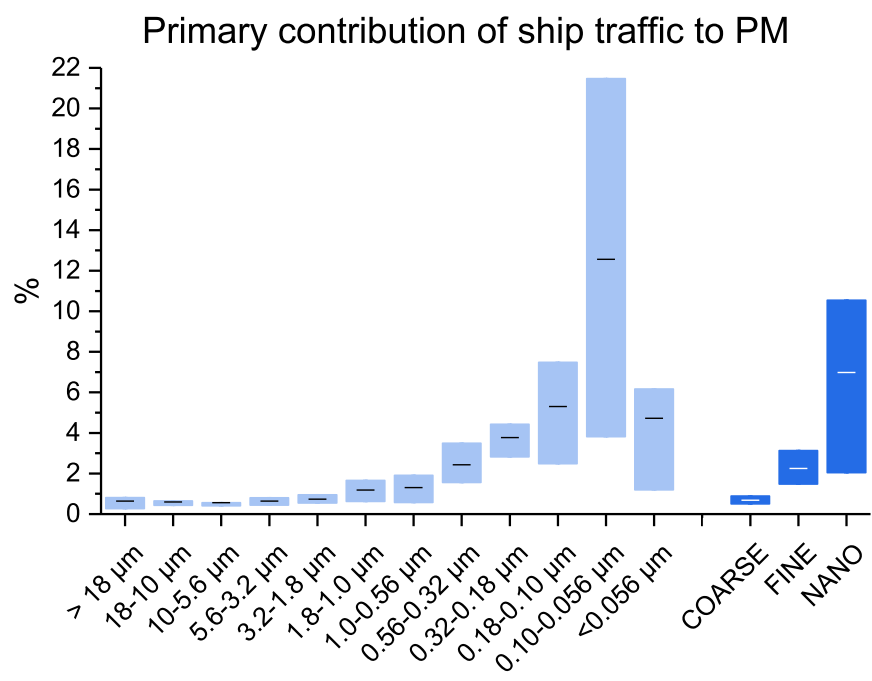

Fig. 3. Primary contribution of ship traffic to PM. The line and the box represent the mean and the interquartile range, respectively.

calculation of the impact of ship traffic to PM was assessed, in the same period and area, applying optical high-resolution measurements of aerosol (Merico et al., 2020): they obtained a contribution of about $2 \%$ to $\mathrm{PM}_{1}$ and of $7.4 \%$ to nanoparticles (in numerical concentration), very similar to the results of this work $\left(2.3 \%\right.$ on $\mathrm{PM}_{1}$ and $7.0 \%$ on $\mathrm{PM}_{0.1}$, respectively). The incremental trend of the contribution with decreasing particle size was in accordance to what previously observed in various sites in Europe (Viana et al., 2014). Specifically, in Europe the comparison has been conducted among $\mathrm{PM}_{10}, \mathrm{PM}_{2.5}$, and $\mathrm{PM}_{1}$, so far. In this work the contribution to $\mathrm{PM}_{1}$ was about 1.8 times higher with respect to the contribution to $\mathrm{PM}_{10}$, comparable to what observed in Spain (Viana et al., 2009) and Lampedusa (Becagli et al., 2012). As to our knowledge the contribution of shipping traffic to nanoparticles/PM $\mathrm{PM}_{0.1}$ is not available in other sites in Europe, with the exclusion of Brindisi and Rijeka, in which measurements were done limited to optical techniques (Merico et al, 2016, 2020).

\subsubsection{Source apportionment by positive matrix factorisation}

After the preliminary dataset refining, seventeen variables were chosen as input for the model using the dataset of coarse particles and eighteen variables for the dataset of fine-nano particles. The number of samples was 90 leading to datasets of 1530 and 1620 values for the coarse and the fine-ultrafine fractions, respectively. The two datasets followed the suggestions of Henry et al. (1984), requiring that the minimum number of samples should be the one that yields a ratio between degrees of freedom and number of variables higher than 60 . Moreover, they also met the requirement of Thurston and Spengler (1985), since the number of samples exceeded the number of variables by a factor higher than three.

Variables were categorized as follows: $\mathrm{SO}_{4}^{2-}, \mathrm{MSA}, \mathrm{Br}^{-}$, oxalate, malonate, malate, $\mathrm{Mn}$, and $\mathrm{Cu}$ were strong in both datasets; $\mathrm{Cl}^{-}, \mathrm{Mg}^{2+}$, $\mathrm{Fe}$, and $\mathrm{Zn}$ were strong in the coarse particles dataset; $\mathrm{NO}_{3}^{-}, \mathrm{NH}_{4}^{+}, \mathrm{V}, \mathrm{Ni}$, $\mathrm{Rb}$, and $\mathrm{Ge}$ were strong in the fine-nano dataset; $\mathrm{NO}_{3}^{-}, \mathrm{K}^{+}, \mathrm{Ti}, \mathrm{V}$ were weak in the coarse particle dataset while succinate, $\mathrm{Fe}$, and $\mathrm{Zn}$ were weak in the fine-nano dataset. $\mathrm{S} / \mathrm{N}$ ratio of variables are reported in the Supplementary Information (Figure S7). An uncertainty of 10\% was added to all variables, in both datasets, taking into account all the components of the overall input data uncertainty, as suggested in Belis et al. (2014). The robustness of solutions was evaluated based on DISP and BS (number of bootstraps: 100; minimum correlation R values: 0.6), following the suggestions given in the PMF User guide (US-EPA, 2014). Starting from the coarse particle dataset, various solutions with different number of factors were considered valid; among them, the solution with 5 factors was selected, based on the trends of the Q-value, IM and IS. In the fine-nano particles run, only the solution with 5 factors was robust based on the BS and DISP error estimation. BS and DISP error estimation parameters are reported in the Supplementary Information (Table S9 and Table S10), together with the errors (Figure S12) for both selected runs. The analysis of G-space plot performed for the factor contributions obtained from the base solutions revealed no evident edges, so the factors were assumed to be linearly independent among them, in both selected solutions (Figures S13 and S14). The comparison of reconstructed concentration by the PMF and the measured values showed that PMF reconstructed the observed concentrations of the coarse fraction with slope 0.93 and $R^{2} 0.95$ and of the fine-nano fraction with slope 0.86 and $\mathrm{R}^{2} 0.87$ (Figure S15).

In Fig. 4, the profiles of each factor obtained from the two datasets are reported in terms of absolute and relative concentrations, with the relative contribution of the factors. The error bars represent the standard deviation of the Bootstrap runs.

The first factor in the run from the coarse particle dataset showed high contribution of MSA, typical tracer of marine biogenic emissions. The factor also showed a contribution of $\mathrm{SO}_{4}^{2-}$ and oxalate, often associated to biogenic emission together with MSA, since they are all products of the algal bloom and contributed for $16 \%$ to total coarse particle mass. The contribution seems to be negligible for a great extent of the sampling period and to rise up in the two last samples, collected in November (Figure S16). Various variables contributed to the second factor, mainly oxalate, malonate, malate, and Ti. The presence of the carboxylic anions links this factor to photo oxidation processes while the contribution of Ti to this factor also suggests a contamination of crustal origin $(\mathrm{EFc}<1)$. The third factor was mainly characterised by the presence of various metals of different origin, such as $\mathrm{V}, \mathrm{Mn}, \mathrm{Fe}, \mathrm{Cu}$, and $\mathrm{Zn}$. $\mathrm{V}$ could be associated to heavy oil combustion, Fe and Mn have generally a crustal origin, $\mathrm{Cu}$ and $\mathrm{Zn}$ are mainly associated to vehicular traffic (Cesari et al., 2014) and showed EFcs $>100$. The fourth factor was associated to sea spray, due to the high contribution of $\mathrm{Mg}^{2+}, \mathrm{NO}_{3}^{-}$, and $\mathrm{Cl}^{-}$; it contributed for $30 \%$ to the coarse particle mass. The fifth factor was characterised by $\mathrm{Cl}^{-}, \mathrm{Br}^{-}$and $\mathrm{Ti}$ (EFc around 1 ), thus it was associated to a mixed source of sea spray and crustal origin, with a contribution of $31 \%$ to PM.

The first factor of the run corresponding to the fine-nano fraction cannot be associated to a specific source, since many variables, related to various origin, contribute to this factor. The second factor was characterised by malonate, malate, $\mathrm{SO}_{4}^{2-}$, and MSA. Carboxylic acids are mostly produced by photochemical oxidation of organic precursors by ozone, $\mathrm{OH}$ radical, NOx and other oxidants, but can be also produced by biomass burning, fossil fuel combustion and urban traffic ( $\mathrm{Fu}$ et al., 2013; Kawamura and Gagosian, 1987; Kawamura and Sakaguchi, 1999). In addition, oxalate has been also associated to the algal bloom (Xu et al., 2013), together with $\mathrm{SO}_{4}^{2-}$ and MSA, typical tracers of marine biogenic emissions. The source was labelled as mix source of photo oxidation and marine biogenic emissions. The third source was characterised by a high contribution of $\mathrm{Ge}$ and $\mathrm{Rb}$, that are crustal elements, and it contributed to $13 \%$ of total mass of fine and nanoparticles. The fourth factor was characterised by $\mathrm{NO}_{3}, \mathrm{NH}_{4}^{+}$, and $\mathrm{Zn}$. The presence of $\mathrm{NH}_{4}^{+}$could be related to the use of nitrogen-fertilizers, while $\mathrm{Zn}$ is mainly related to traffic emissions. $\mathrm{NO}_{3}^{-}$could be associated to both sources, given that could be produced by the oxidation of $\mathrm{NH}_{4}^{+}$from agriculture and of nitrogen oxides generated by traffic. The source, associated to agriculture and traffic, had a significant contribution only from August to the beginning of October (Figure S17). After that moment, the contribution was negligible. The last factor was characterised by $\mathrm{V}$ and $\mathrm{Ni}$; thus, it could be associated to heavy oil combustion from industrial activities or shipping emissions. The high concentration of $\mathrm{Ni}$ in the factor (V/Ni: 0.7) suggests a relevant contribution of industrial emissions, given that heavy oil combustion may be identified by the concentration ratio $\mathrm{V} / \mathrm{Ni}$ of about 2.5-5 (Viana et al., 2009). Otherwise, a contamination by shipping emissions in this area is expected, since the monitoring station is very close to the harbour. The contribution of this 
a)

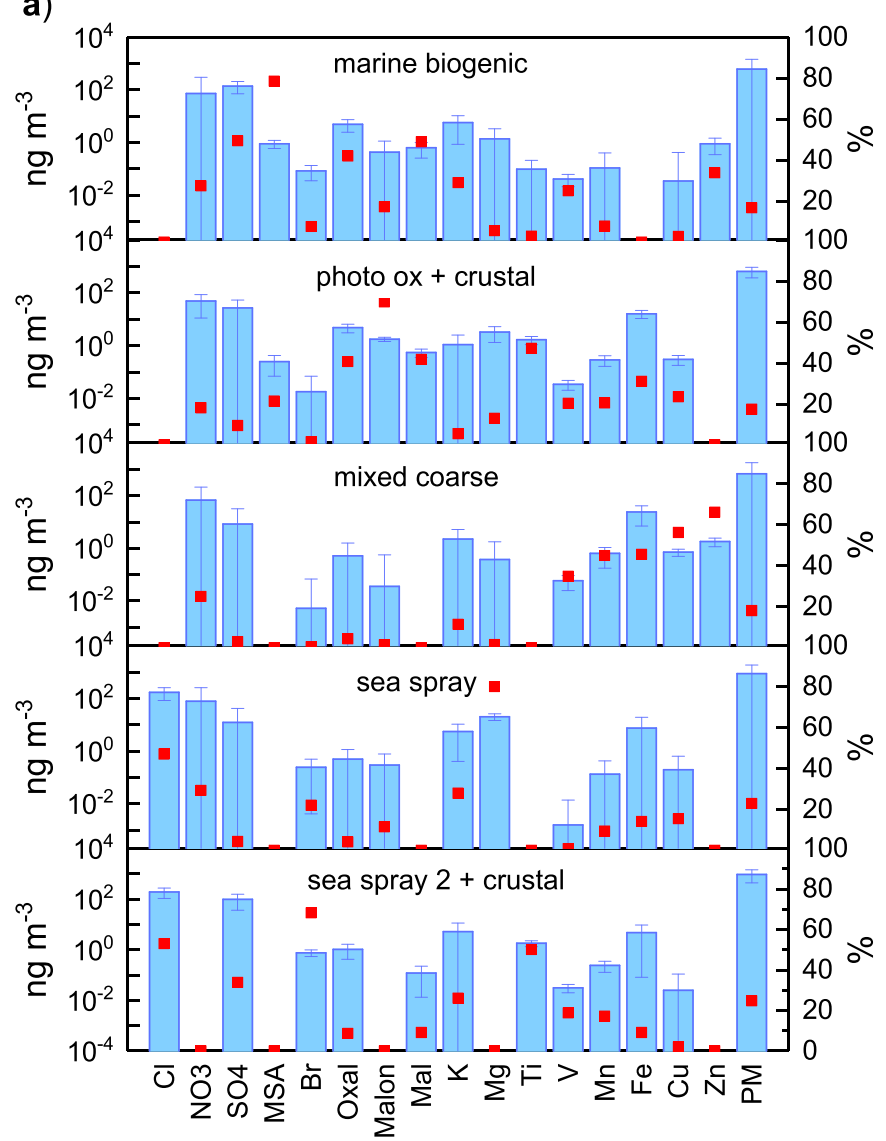

b)

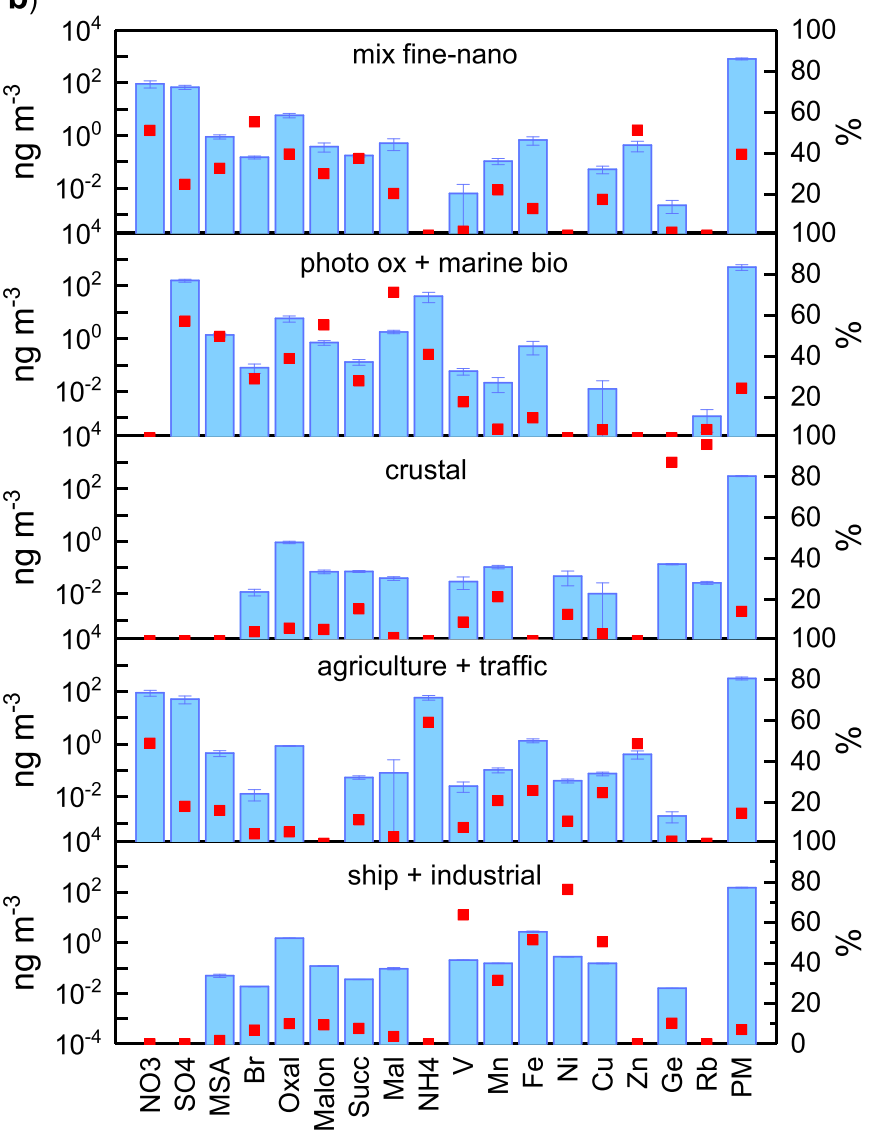

c)

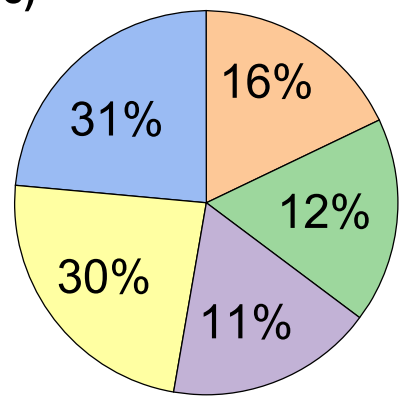

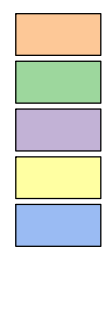

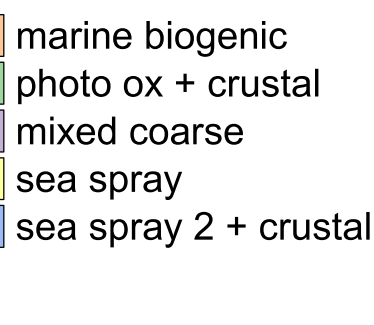

d)

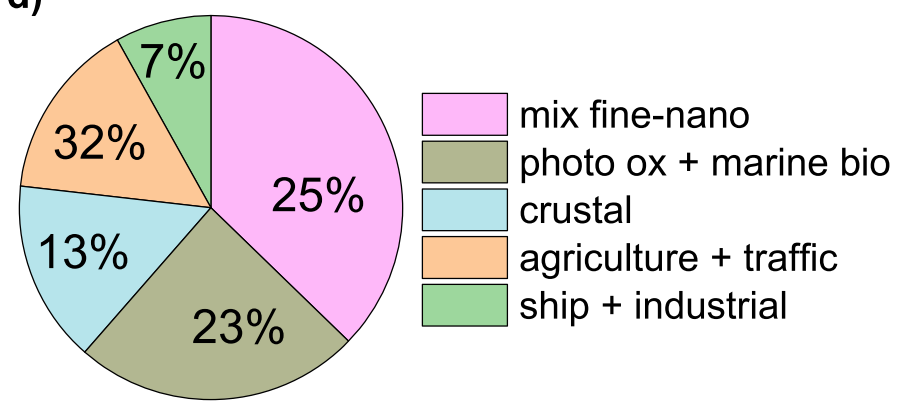

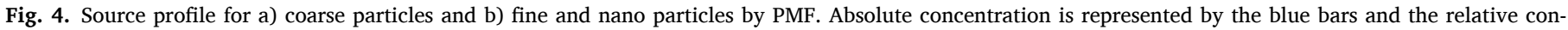

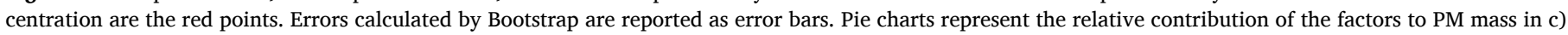
coarse particles; d) fine and nano particles.

factor decreased passing from summer to fall, coherent with the expected trend of a ship emission source. The relative contribution of the fifth factor $(7 \%)$ was higher to that previously reported for shipping emissions to $\mathrm{PM}_{1}$ (Figure S11), suggesting finally a mixed source of shipping plus industrial emission. This factor was extracted only in the fine-nano particle run, that is coherent to the fact that fossil fuel combustion dominated the production of aerosol in the fine mode (Masalaite et al., 2018).

PMF selected solutions showed some mixed sources, probably due to the variability of the datasets, constituted of aerosol of twelve different size ranges. Despite that, some sources have been clearly identified. Sea spray was identified only in the coarse fraction, in two different factors. The relative contribution of the sea spray factor (forth factor extracted from the coarse particle dataset, 30\%) was higher with respect to that calculated using the approximate formula (18\%) and similar to that calculated by Contini et al. (2014), in Lecce (Italy) using the same approach with size-segregated data. Barbaro et al. (2019), in the urban area of Mestre (Venice), identified an aged sea spray source, with contribution of $50 \%$. An interesting source to be investigated is that correlated with maritime traffic. In this work, ship traffic was part of a mixed source, as often happens using PMF (Viana et al., 2014). However, that source was identified only in the fine-ultrafine particles, where generally the contribution of ship traffic is higher, and the chronological trend was that expected for maritime traffic emissions. The average contribution (7\%) was higher with respect to that calculated for $\mathrm{PM}_{1}$ using the formula by Agrawal et al. (2009) and similar to 
that observed by Amato et al. (2009) in Barcelona (Spain, 8\%), using $\mathrm{PM}_{1}$ data and the same approach. Brines et al. (2019) identified ship traffic in a mixed PMF factor with secondary inorganic aerosol, with contribution of $16 \%$ and $24 \%$ in different conditions, in Barcelona (Spain). Both solutions were robust, as all factors were mapped and showed no rotational ambiguity (§2.3.3, Tables SI7 and SI8). A swap was observed between the fourth and fifth factors of the solution obtained from the coarse particles dataset, probably due to the common origin of $\mathrm{Cl}^{-}$from sea spray; the solution from the fine-nano particles dataset showed no swaps.

\section{Conclusions}

The size distribution of aerosol, and in particular of ionic species, trace metals, and carbonaceous species concentration were studied from August to November 2018, in Sacca Fisola (Venice). Correlation coefficients between chemicals, a comparison of the size distribution, and the calculus of enrichment factors gave support to the results of the source apportionment, carried out based on two different approaches. The use of approximated formulae permitted to cover the most important sources of aerosol, excepting crustal emissions, not evaluated in this work, due to missing information about silicon. PMF factors often represented mixed sources and, among these, marine biogenic emissions, sea spray, and crustal emissions were clearly identified. Other sources, such as maritime traffic, industrial emissions, agriculture, road traffic, and photochemical oxidation, were mixed.

Chemical characterisation of nanoparticles is not so common in literature, because of difficulties in sampling and analysing so little quantity of particulate matter. With this work we faced this challenging topic, evidencing how some minor sources in total particulate may instead become significant, changing point of view towards sizesegregated aerosol. As an example, we found out that primary anthropogenic aerosol and shipping emissions increased as particle dimension decreased, being maximum in nanoparticles. Source apportionment evidenced that fine and ultrafine particles are generated mainly by anthropogenic activities, confirming the need of more size-segregated studies for investigating the impact of human activities to air pollution.

\section{Declaration of competing interest}

The authors declare that they have no known competing financial interests or personal relationships that could have appeared to influence the work reported in this paper.

\section{Acknowledgements}

This work was performed within the framework of the project "ECOlogical supporting for traffic Management in cOastal areas By using an InteLlIgenTsYstem" (ECOMOBILITY, Interreg Italy-Croatia 2014-2020, grant nr. 10043082); the financial support of the European Regional Development Fund (ERDF) and national sources is gratefully acknowledged. The authors thank the Regional Agency for Environmental Prevention and Protection of Veneto (ARPAV) for the availability of the monitoring site in Sacca Fisola; Luca Sorarù and Alvise Ardizzon for the sampling and analysis activities.

\section{Appendix A. Supplementary data}

Supplementary data to this article can be found online at https://doi. org/10.1016/j.apr.2020.11.007.

\section{References}

Agrawal, H., Eden, R., Zhang, X., Fine, P.M., Katzenstein, A., Miller, J.W., Ospital, J., Teffera, S., Cocker, D.R., 2009. Primary particulate matter from ocean-going engines in the Southern California Air Basin. Environ. Sci. Technol. 43, 5398-5402. https:// doi.org/10.1021/es8035016.
Amato, F., Pandolfi, M., Escrig, A., Querol, X., Alastuey, A., Pey, J., Perez, N., Hopke, P. K., 2009. Quantifying road dust resuspension in urban environment by Multilinear Engine: a comparison with PMF2. Atmos. Environ. 43, 2770-2780. https://doi.org/ 10.1016/j.atmosenv.2009.02.039.

Arı, A., Arı, P.E., Gaga, E.O., 2020. Chemical characterization of size-segregated particulate matter (PM) by inductively coupled plasma - tandem mass spectrometry (ICP-MS/MS). Talanta 208, 120350. https://doi.org/10.1016/J. TALANTA.2019.120350.

Barbaro, E., Padoan, S., Kirchgeorg, T., Zangrando, R., Toscano, G., Barbante, C., Gambaro, A., 2017. Particle size distribution of inorganic and organic ions in coastal and inland Antarctic aerosol. Environ. Sci. Pollut. Res. 24, 2724-2733. https://doi. org/10.1007/s11356-016-8042-x.

Barbaro, E., Feltracco, M., Cesari, D., Padoan, S., Zangrando, R., Contini, D., Barbante, C., Gambaro, A., 2019. Characterization of the water soluble fraction in ultrafine, fine, and coarse atmospheric aerosol. Sci. Total Environ. 658, 1423-1439. https://doi. org/10.1016/j.scitotenv.2018.12.298.

Becagli, S., Sferlazzo, D.M., Pace, G., Di Sarra, A., Bommarito, C., Calzolai, G., Ghedini, C., Lucarelli, F., Meloni, D., Monteleone, F., Severi, M., Traversi, R., Udisti, R., 2012. Evidence for heavy fuel oil combustion aerosols from chemical analyses at the island of Lampedusa: a possible large role of ships emissions in the Mediterranean. Atmos. Chem. Phys. 12, 3479-3492. https://doi.org/10.5194/acp12-3479-2012.

Belis, C.A., Larsen, B.R., Amato, F., Haddad, E., Favez, O., Harrison, R.M., Hopke, P.K., Nava, S., Paatero, P., Prévôt, A., Quass, U., Vecchi, R., Viana, M., 2014. JRC Reference Reports: European Guide on Air Pollution Source Apportionment with Receptor Models. https://doi.org/10.2788/9307.

Bernardoni, V., Elser, M., Valli, G., Valentini, S., Bigi, A., Fermo, P., Piazzalunga, A., Vecchi, R., 2017. Size-segregated aerosol in a hot-spot pollution urban area: chemical composition and three-way source apportionment. Environ. Pollut. 231, 601-611. https://doi.org/10.1016/j.envpol.2017.08.040.

Bressi, M., Sciare, J., Ghersi, V., Bonnaire, N., Nicolas, J.B., Petit, J.E., Moukhtar, S., Rosso, A., Mihalopoulos, N., Féron, A., 2013. A one-year comprehensive chemical characterisation of fine aerosol (PM2.5) at urban, suburban and rural background sites in the region of Paris (France). Atmos. Chem. Phys. 13, 7825-7844. https://doi. org/10.5194/acp-13-7825-2013.

Brines, M., Dall'Osto, M., Amato, F., Minguillón, M.C., Karanasiou, A., Grimalt, J.O., Alastuey, A., Querol, X., van Drooge, B.L., 2019. Source apportionment of urban PM1 in Barcelona during SAPUSS using organic and inorganic components. Environ. Sci. Pollut. Res. 26, 32114-32127. https://doi.org/10.1007/s11356-019-06199-3.

Canepari, S., Astolfi, M.L., Catrambone, M., Frasca, D., Marcoccia, M., Marcovecchio, F., Massimi, L., Rantica, E., Perrino, C., 2019. A combined chemical/size fractionation approach to study winter/summer variations, ageing and source strength of atmospheric particles. Environ. Pollut. 253, 19-28. https://doi.org/10.1016/j. envpol.2019.06.116.

Castro, L.M., Pio, C.A., Harrison, R.M., Smith, D.J.T., 1999. Carbonaceous aerosol in urban and rural European atmospheres : estimation of secondary organic carbon concentrations. Atmos. Environ. 33, 2771-2781. https://doi.org/10.1016/S13522310(98)00331-8.

Cesari, D., Genga, a., Ielpo, P., Siciliano, M., Mascolo, G., Grasso, F.M., Contini, D., 2014. Source apportionment of PM2.5 in the harbour-industrial area of Brindisi (Italy): identification and estimation of the contribution of in-port ship emissions. Sci. Total Environ. 497-498, 392-400. https://doi.org/10.1016/j.scitotenv.2014.08.007.

Cesari, D., Merico, E., Dinoi, A., Gambaro, A., Morabito, E., Gregoris, E., Barbaro, E., Feltracco, M., Alebić-Juretić, A., Odorčić, D., Kontošić, D., Mifka, B., Contini, D., 2020. An inter-comparison of size segregated carbonaceous aerosol collected by lowvolume impactor in the port-cities of Venice (Italy) and Rijeka (Croatia). Atmos. Pollut. Res. 11, 1705-1714. https://doi.org/10.1016/j.apr.2020.06.027.

Chen, L., Wang, J., Gao, Y., Xu, G., Yang, X., Lin, Q., Zhang, Y., 2012. Latitudinal distributions of atmospheric MSA and MSA/nss-SO 42- ratios in summer over the high latitude regions of the Southern and Northern Hemispheres. J. Geophys. Res. Atmos. 117, 1-10. https://doi.org/10.1029/2011JD016559.

Contini, D., Genga, A., Cesari, D., Siciliano, M., Donateo, A., Bove, M.C., Guascito, M.R., 2010. Characterisation and source apportionment of PM10 in an urban background site in Lecce. Atmos. Res. 95, 40-54. https://doi.org/10.1016/J. ATMOSRES.2009.07.010.

Contini, D., Gambaro, A., Belosi, F., De Pieri, S., Cairns, W.R.L., Donateo, A., Zanotto, E., Citron, M., 2011. The direct influence of ship traffic on atmospheric PM2.5, PM10 and PAH in Venice. J. Environ. Manag. 92, 2119-2129. https://doi.org/10.1016/j. jenvman.2011.01.016.

Contini, D., Belosi, F., Gambaro, A., Cesari, D., Stortini, A.M., Bove, M.C., 2012. Comparison of PM10 concentrations and metal content in three different sites of the Venice Lagoon: an analysis of possible aerosol sources. J. Environ. Sci. (China) 24. https://doi.org/10.1016/S1001-0742(11)61027-9, 1954-1965.

Contini, D., Cesari, D., Genga, a., Siciliano, M., Ielpo, P., Guascito, M.R., Conte, M., 2014. Source apportionment of size-segregated atmospheric particles based on the major water-soluble components in Lecce (Italy). Sci. Total Environ. 472, 248-261. https://doi.org/10.1016/j.scitotenv.2013.10.127.

Contini, D., Gambaro, A., Donateo, A., Cescon, P., Cesari, D., Merico, E., Belosi, F., Citron, M., 2015. Inter-annual trend of the primary contribution of ship emissions to PM2.5 concentrations in Venice (Italy): efficiency of emissions mitigation strategies. Atmos. Environ. 102, 183-190. https://doi.org/10.1016/j.atmosenv.2014.11.065.

Corami, F., Morabito, E., Gambaro, A., Cescon, P., Libralato, G., Picone, M., Ghirardini, A.V., Barbante, C., 2020. Geospeciation, toxicological evaluation, and hazard assessment of trace elements in superficial and deep sediments. Environ. Sci. Pollut. Res. 27, 15565-15583. https://doi.org/10.1007/s11356-020-07784-7. 
Dabek-Zlotorzynska, E., Celo, V., Ding, L., Herod, D., Jeong, C.H., Evans, G., Hilker, N., 2019. Characteristics and sources of PM2.5 and reactive gases near roadways in two metropolitan areas in Canada. Atmos. Environ. 218, 116980. https://doi.org/ 10.1016/j.atmosenv.2019.116980.

Donateo, A., Gregoris, E., Gambaro, A., Merico, E., Giua, R., Nocioni, A., Contini, D. 2014. Contribution of harbour activities and ship traffic to PM2.5, particle number concentrations and PAHs in a port city of the Mediterranean Sea (Italy). Environ. Sci. Pollut. Res. 21, 9415-9429. https://doi.org/10.1007/s11356-014-2849-0.

Dordević, D., Mihajlidi-Zelić, A., Relić, D., Ignjatović, L., Huremović, J., Stortini, A.M. Gambaro, A., 2012. Size-segregated mass concentration and water soluble inorganic ions in an urban aerosol of the Central Balkans (Belgrade). Atmos. Environ. 46, 309-317. https://doi.org/10.1016/j.atmosenv.2011.09.057.

Enamorado-Báez, S.M., Gómez-Guzmán, J.M., Chamizo, E., Abril, J.M., 2015. Levels of 25 trace elements in high-volume air filter samples from seville (2001-2002): sources, enrichment factors and temporal variations. Atmos. Res. 155, 118-129. https://doi.org/10.1016/j.atmosres.2014.12.005.

Feltracco, M., Barbaro, E., Contini, D., Zangrando, R., Toscano, G., Battistel, D., Barbante, C., Gambaro, A., 2018. Photo-oxidation products of A-pinene in coarse, fine and ultrafine aerosol: a new high sensitive HPLC-MS/MS method. Atmos. Environ. 180, 149-155. https://doi.org/10.1016/j.atmosenv.2018.02.052.

Feltracco, M., Barbaro, E., Tedeschi, S., Spolaor, A., Turetta, C., Vecchiato, M. Morabito, E., Zangrando, R., Barbante, C., Gambaro, A., 2020. Interannual variability of sugars in Arctic aerosol: biomass burning and biogenic inputs. Sci. Total Environ. 706, 136089. https://doi.org/10.1016/j.scitotenv.2019.136089.

Fu, P., Kawamura, K., Usukura, K., Miura, K., 2013. Dicarboxylic acids, ketocarboxylic acids and glyoxal in the marine aerosols collected during a round-the-world cruise. Mar. Chem. 148, 22-32. https://doi.org/10.1016/j.marchem.2012.11.002.

Fujitani, Y., Hasegawa, S., Fushimi, A., Kondo, Y., Tanabe, K., Kobayashi, S., Kobayashi, T., 2006. Collection characteristics of low-pressure impactors with various impaction substrate materials. Atmos. Environ. 40, 3221-3229. https://doi. org/10.1016/j.atmosenv.2006.02.001.

Gondwe, M., Krol, M., Gieskes, W., Klaassen, W., de Baar, H., 2003. The contribution of ocean-leaving DMS to the global atmospheric burdens of DMS, MSA, SO 2 , and NSS SO 4 =. Global Biogeochem. Cycles 17, 1056. https://doi.org/10.1029/ 2002 gb001937.

Gregoris, E., Barbaro, E., Gambaro, A., Contini, D., 2016. Impact of maritime traffic on polycyclic aromatic hydrocarbons, metals and particulate matter in Venice air. Environ. Sci. Pollut. Res. 23, 6951-6959. https://doi.org/10.1007/s11356-0155811-x.

Healy, R.M., Hellebust, S., Kourtchev, I., Allanic, A., O'Connor, I.P., Bell, J.M., Healy, D. a., Sodeau, J.R., Wenger, J.C., 2010. Source apportionment of PM2.5 in Cork Harbour, Ireland using a combination of single particle mass spectrometry and quantitative semi-continuous measurements. Atmos. Chem. Phys. 10, 9593-9613. https://doi.org/10.5194/acp-10-9593-2010.

Henry, R.C., Lewis, C.W., Hopke, P.K., Williamson, H.J., 1984. Review of receptor model fundamentals. Atmos. Environ. 18, 1507-1515. https://doi.org/10.1016/0004-6981 (84)90375-5.

Herner, J., Ying, Q., Aw, J., Gao, O., Chang, D., Kleeman, M., 2006. Dominant mechanisms that shape the airborne particle size and composition distribution in Central California. Aerosol Sci. Technol. 40, 827-844. https://doi.org/10.1080/ 02786820600728668.

Hoet, P.H.M., Brüske-Hohlfeld, I., Salata, O.V., 2004. Nanoparticles - known and unknown health risks. J. Nanobiotechnol. https://doi.org/10.1186/1477-3155-2-12.

Jiang, S.Y., Kaul, D.S., Yang, F., Sun, L., Ning, Z., 2015. Source apportionment and wate solubility of metals in size segregated particles in urban environments. Sci. Total Environ. 533, 347-355. https://doi.org/10.1016/J.SCITOTENV.2015.06.146.

Kaneyasu, N., Yoshikado, H., Mizuno, T., Sakamoto, K., Soufuku, M., 1999. Chemical forms and sources of extremely high nitrate and chloride in winter aerosol pollution in the Kanto Plain of Japan. Atmos. Environ. 33, 1745-1756. https://doi.org/ 10.1016/S1352-2310(98)00396-3.

Kawamura, K., Gagosian, R.B., 1987. Implications of $\omega$-Oxocarboxylic acids in the remote marine atmosphere for photo-Oxidation of unsaturated fatty acids. Nature 325 , 330-332. https://doi.org/10.1038/325330a0.

Kawamura, K., Sakaguchi, F., 1999. Molecular distributions of water soluble dicarboxylic acids in marine aerosols over the Pacific Ocean including tropics. J. Geophys. Res. Atmos. 104, 3501-3509. https://doi.org/10.1029/1998JD100041.

Kawanaka, Y., Matsumoto, E., Sakamoto, K., Wang, N., Yun, S.J., 2004. Size distributions of mutagenic compounds and mutagenicity in atmospheric particulate matter collected with a low-pressure cascade impactor. Atmos. Environ. 38, 2125-2132. https://doi.org/10.1016/j.atmosenv.2004.01.021.

Kim, K.H., Kabir, E., Kabir, S., 2015. A review on the human health impact of airborne particulate matter. Environ. Int. 74, 136-143. https://doi.org/10.1016/j. envint.2014.10.005.

Kumar, P., Kumar, S., Yadav, S., 2018. Seasonal variations in size distribution, watersoluble ions, and carbon content of size-segregated aerosols over New Delhi. Environ. Sci. Pollut. Res. 25, 6061-6078. https://doi.org/10.1007/s11356-0170954-6.

Kumar, A., Sankar, T.K., Sethi, S.S., Ambade, B., 2019. Characteristics, toxicity, source identification and seasonal variation of atmospheric polycyclic aromatic hydrocarbons over East India. Environ. Sci. Pollut. Res. 27, 678-690. https://doi. org/10.1007/s11356-019-06882-5.

Li, T.-C., Yuan, C.-S., Hung, C.-H., Lin, H.-Y., Huang, H.-C., Lee, C.-L., 2016. Chemical characteristics of marine fine aerosols over sea and at offshore islands during three cruise sampling campaigns in the taiwan Strait- sea salts and anthropogenic particles. Atmos. Chem. Phys. Discuss. 1-27. https://doi.org/10.5194/acp-2016384.
Lyu, X.P., Wang, Z.W., Cheng, H.R., Zhang, F., Zhang, G., Wang, X.M., Ling, Z.H., Wang, N., 2015. Chemical characteristics of submicron particulates (PM1.0) in Wuhan, Central China. Atmos. Res. 161-162, 169-178. https://doi.org/10.1016/j. atmosres.2015.04.009.

Malandrino, M., Casazza, M., Abollino, O., Minero, C., Maurino, V., 2016. Size resolved metal distribution in the PM matter of the city of Turin (Italy). Chemosphere 147 477-489. https://doi.org/10.1016/j.chemosphere.2015.12.089.

Mamoudou, I., Zhang, F., Chen, Q., Wang, P., Chen, Y., 2018. Characteristics of PM2.5 from ship emissions and their impacts on the ambient air: a case study in Yangshan Harbor. Shanghai. Sci. Total Environ. 640-641, 207-216. https://doi.org/10.1016/j. scitotenv.2018.05.261.

Martin, C., 2010. Venice's fragile lagoon. Nature 467, 529.

Martins, V., Faria, T., Diapouli, E., Manousakas, M.I., Eleftheriadis, K., Viana, M., Almeida, S.M., 2020. Relationship between indoor and outdoor size-fractionated particulate matter in urban microenvironments: levels, chemical composition and sources. Environ. Res. 183, 109203. https://doi.org/10.1016/J, ENVRES.2020.109203.

Masalaite, A., Holzinger, R., Ceburnis, D., Remeikis, V., Ulevičius, V., Röckmann, T., Dusek, U., 2018. Sources and atmospheric processing of size segregated aerosol particles revealed by stable carbon isotope ratios and chemical speciation. Environ. Pollut. 240, 286-296. https://doi.org/10.1016/j.envpol.2018.04.073.

Masiol, M., Rampazzo, G., Ceccato, D., Squizzato, S., Pavoni, B., 2010. Characterization of PM10 sources in a coastal area near Venice (Italy): an application of factor-cluster analysis. Chemosphere 80, 771-778. https://doi.org/10.1016/J. CHEMOSPHERE.2010.05.008.

Masiol, M., Squizzato, S., Ceccato, D., Rampazzo, G., Pavoni, B., 2012a. Determining the influence of different atmospheric circulation patterns on PM10 chemical composition in a source apportionment study. Atmos. Environ. 63, 117-124. https:// doi.org/10.1016/J.ATMOSENV.2012.09.025.

Masiol, M., Squizzato, S., Ceccato, D., Rampazzo, G., Pavoni, B., 2012b. A chemometric approach to determine local and regional sources of PM10 and its geochemical composition in a coastal area. Atmos. Environ. 54, 127-133. https://doi.org/ 10.1016/J.ATMOSENV.2012.02.089.

Masiol, M., Squizzato, S., Ceccato, D., Pavoni, B., 2015. The size distribution of chemical elements of atmospheric aerosol at a semi-rural coastal site in Venice (Italy). The role of atmospheric circulation. Chemosphere 119, 400-406. https://doi.org/10.1016/j. chemosphere. 2014.06.086.

Mazzei, F., D’Alessandro, A., Lucarelli, F., Nava, S., Prati, P., Valli, G., Vecchi, R., 2008. Characterization of particulate matter sources in an urban environment. Sci. Total Environ. 401, 81-89. https://doi.org/10.1016/j.scitotenv.2008.03.008.

McInnes, M.L., Covert, D.S., Quinn, P.K., Germani, M.S., 1994. Measurements of chloride depletion and sulfur enrichment in individual sea-salt particles collected from the remote marine boundary layer. J. Geophys. Res. Atmos. 99, 8257-8268. https://doi. org/10.1029/93JD03453.

Merico, E., Donateo, A., Gambaro, A., Cesari, D., Gregoris, E., Barbaro, E., Dinoi, A., Giovanelli, G., Masieri, S., Contini, D., 2016. Influence of in-port ships emissions to gaseous atmospheric pollutants and to particulate matter of different sizes in a Mediterranean harbour in Italy. Atmos. Environ. 139, 1-10. https://doi.org/ 10.1016/j.atmosenv.2016.05.024.

Merico, E., Cesari, D., Dinoi, A., Gambaro, A., Barbaro, E., Guascito, M.R., Giannossa, L. C., Mangone, A., Contini, D., 2019a. Inter-comparison of carbon content in PM 10 and PM 2 . 5 measured with two thermo-optical protocols on samples collected in a Mediterranean site. Environ. Sci. Pollut. Res. 26, 29334-29350. https://doi.org/ 10.1007/s11356-019-06117-7.

Merico, E., Dinoi, A., Contini, D., 2019b. Development of an integrated modellingmeasurement system for near-real-time estimates of harbour activity impact to atmospheric pollution in coastal cities. Transport. Res. Transport Environ. 73, 108-119. https://doi.org/10.1016/j.trd.2019.06.009.

Merico, E., Conte, M., Grasso, F.M., Cesari, D., Gambaro, A., Morabito, E., Gregoris, E., Orlando, S., Alebić-Juretić, A., Zubak, V., Mifka, B., Contini, D., 2020. Comparison of the impact of ships to size-segregated particle concentrations in two harbour cities of northern Adriatic Sea. Environ. Pollut. 266 https://doi.org/10.1016/j. envpol.2020.115175.

Morabito, E., Gregoris, E., Belosi, F., Contini, D., Cesari, D., Gambaro, A., Deary, M.E., 2020. Multi-Year concentrations, health risk, and source identification, of air toxics in the Venice lagoon. Front. Environ. Sci. 8, 1-17. https://doi.org/10.3389/ fenvs.2020.00107.

Morales, J.A., Pirela, D., De Nava, M.G., De Borrego, B.S., Velásquez, H., Durán, J., 1998. Inorganic water soluble ions in atmospheric particles over Maracaibo Lake Basin in the western region of Venezuela. Atmos. Res. 46, 307-320. https://doi.org/ 10.1016/S0169-8095(97)00071-9.

Paatero, J., Ioannidou, A., Ikonen, J., Lehto, J., 2017. Aerosol particle size distribution of atmospheric lead-210 in northern Finland. J. Environ. Radioact. 172, 10-14. https:// doi.org/10.1016/j.jenvrad.2017.03.003.

Pachon, J.E., Weber, R.J., Zhang, X., Mulholland, J.A., Russell, A.G., 2013. Revising the use of potassium (K) in the source apportionment of PM2.5. Atmos. Pollut. Res. 4, 14-21. https://doi.org/10.5094/APR.2013.002.

Perrino, C., Canepari, S., Catrambone, M., Dalla Torre, S., Rantica, E., Sargolini, T., 2009. Influence of natural events on the concentration and composition of atmospheric particulate matter. Atmos. Environ. 43, 4766-4779. https://doi.org/10.1016/j. atmosenv.2008.06.035.

Perrino, C., Canepari, S., Catrambone, M., 2013. Comparing the performance of Teflon and quartz membrane filters collecting atmospheric PM: influence of atmospheric water. Aerosol Air Qual. Res. 13, 137-147. https://doi.org/10.4209/ aaqr.2012.07.0167. 
Popovicheva, O., Kireeva, E., Shonija, N., Zubareva, N., Persiantseva, N., Tishkova, V., Demirdjian, B., Moldanová, J., Mogilnikov, V., 2009. Ship particulate pollutants: characterization in terms of environmental implication. J. Environ. Monit. 11, 2077-2086. https://doi.org/10.1039/b908180a.

Pöschl, U., 2005. Atmospheric aerosols: composition, transformation, climate and health effects. Angew. Chem. Int. Ed. 44, 7520-7540. https://doi.org/10.1002/ anie. 200501122.

Prodi, F., Belosi, F., Contini, D., Santachiara, G., Di Matteo, L., Gambaro, A., Donateo, A., Cesari, D., 2009. Aerosol fine fraction in the Venice Lagoon: particle composition and sources. Atmos. Res. 92, 141-150. https://doi.org/10.1016/j. atmosres.2008.09.020.

Rampazzo, G., Masiol, M., Visin, F., Rampado, E., Pavoni, B., 2008. Geochemical characterization of PM10 emitted by glass factories in Murano, Venice (Italy). Chemosphere 71, 2068-2075. https://doi.org/10.1016/j. chemosphere.2008.01.039.

Rosenfeld, D., Sherwood, S., Wood, R., Donner, L., 2014. Climate effects of aerosol-cloud interactions. Science 343, 379-380. https://doi.org/10.1126/science.1247490.

Rossini, P., De Lazzari, A., Guerzoni, S., Molinaroli, E., Rampazzo, G., Zancanaro, A., 2001. Atmospheric input of organic pollutants to the Venice Lagoon. Ann. Chim. 91 491-501.

Rovelli, S., Cattaneo, A., Nischkauer, W., Borghi, F., Spinazzè, A., Keller, M., Campagnolo, D., Limbeck, A., Cavallo, D.M., 2020. Toxic trace metals in sizesegregated fine particulate matter: mass concentration, respiratory deposition, and risk assessment. Environ. Pollut. 266, 115242. https://doi.org/10.1016/j. envpol.2020.115242.

Sciare, J., Oikonomou, K., Cachier, H., Mihalopoulos, N., Andreae, M.O., Maenhaut, W., Sarda-Estève, R., 2005. Aerosol mass closure and reconstruction of the light scattering coefficient over the Eastern Mediterranean Sea during the MINOS campaign. Atmos. Chem. Phys. 5, 2253-2265. https://doi.org/10.5194/acp-5-22532005.

Shiraiwa, M., Selzle, K., Pöschl, U., 2012. Hazardous components and health effects of atmospheric aerosol particles: reactive oxygen species, soot, polycyclic aromatic compounds and allergenic proteins. Free Radic. Res. https://doi.org/10.3109/ 10715762.2012.663084.

Singh, A., Rastogi, N., Patel, A., Singh, D., 2016. Seasonality in size-segregated ionic composition of ambient particulate pollutants over the Indo-Gangetic Plain: source apportionment using PMF. Environ. Pollut. 219, 906-915. https://doi.org/10.1016/ j.envpol.2016.09.010.

Sorte, S., Rodrigues, V., Borrego, C., Monteiro, A., 2020. Impact of harbour activities on local air quality: a review. Environ. Pollut. https://doi.org/10.1016/j. envpol.2019.113542.

Stortini, A.M., Freda, A., Cesari, D., Cairns, W.R.L., Contini, D., Barbante, C., Prodi, F., Cescon, P., Gambaro, A., 2009. An evaluation of the PM2.5 trace elemental composition in the Venice Lagoon area and an analysis of the possible sources. Atmos. Environ. 43, 6296-6304. https://doi.org/10.1016/j.atmosenv.2009.09.033.

Sulejmanović, J., Muhić-Šarac, T., Memić, M., Gambaro, A., Selović, A., 2014. Trace metal concentrations in size-fractionated urban atmospheric particles of Sarajevo, Bosnia and Herzegovina. Int. J. Environ. Res. 8, 711-718. https://doi.org/10.22059/ IJER.2014.764.

Sun, Z., Mu, Y., Liu, Y., Shao, L., 2013. A comparison study on airborne particles during haze days and non-haze days in Beijing. Sci. Total Environ. 456-457, 1-8. https:// doi.org/10.1016/j.scitotenv.2013.03.006.

Taiwo, A.M., Beddows, D.C.S., Shi, Z., Harrison, R.M., 2014. Mass and number size distributions of particulate matter components: comparison of an industrial site and an urban background site. Sci. Total Environ. 475, 29-38. https://doi.org/10.1016/ j.scitotenv.2013.12.076.
Thurston, G.D., Spengler, J.D., 1985. A quantitative assessment of source contributions to inhalable particulate matter pollution in metropolitan Boston. Atmos. Environ. 19, 9-25. https://doi.org/10.1016/0004-6981(85)90132-5.

Toscano, G., Moret, I., Gambaro, A., Barbante, C., Capodaglio, G., 2011. Distribution and seasonal variability of trace elements in atmospheric particulate in the Venice Lagoon. Chemosphere 85, 1518-1524. https://doi.org/10.1016/j. chemosphere.2011.09.045.

Turpin, B.J., Lim, H.J., 2001. Species contributions to pm2.5 mass concentrations: revisiting common assumptions for estimating organic mass. Aerosol Sci. Technol. 35, 602-610. https://doi.org/10.1080/02786820119445.

Turšič, J., Podkrajšek, B., Grgić, I., Ctyroky, P., Berner, A., Dusek, U., Hitzenberger, R., 2006. Chemical composition and hygroscopic properties of size-segregated aerosol particles collected at the Adriatic coast of Slovenia. Chemosphere 63, 1193-1202. https://doi.org/10.1016/j.chemosphere.2005.08.040.

US-EPA, 2014. EPA Positive Matrix Factorization (PMF) 5.0 Fundamentals and User Guide.

Vecchi, R., Valli, G., Fermo, P., D’Alessandro, A., Piazzalunga, A., Bernardoni, V., 2009. Organic and inorganic sampling artefacts assessment. Atmos. Environ. 43, 1713-1720. https://doi.org/10.1016/j.atmosenv.2008.12.016.

Viana, M., Amato, F., Alastuey, A., Querol, X., Moreno, T., Dos Santos, S.G., Herce, M.D., Fernández-Patier, R., 2009. Chemical tracers of particulate emissions from commercial shipping. Environ. Sci. Technol. 43, 7472-7477. https://doi.org/ 10.1021/es901558t.

Viana, M., Hammingh, P., Colette, A., Querol, X., Degraeuwe, B., Vlieger, I., De van Aardenne, J., 2014. Impact of maritime transport emissions on coastal air quality in Europe. Atmos. Environ. 90, 96-105. https://doi.org/10.1016/j. atmosenv.2014.03.046.

Wang, J., Ho, S.S.H., Cao, J., Huang, R., Zhou, J., Zhao, Y., Xu, H., Liu, S., Wang, G., Shen, Z., Han, Y., 2015. Characteristics and major sources of carbonaceous aerosols in PM2.5 from Sanya, China. Sci. Total Environ. 530-531, 110-119. https://doi.org/ 10.1016/j.scitotenv.2015.05.005.

Wedepohl, H.K., 1995. The composition of the continental crust. Geochem. Cosmochim. Acta 59, 1217-1232. https://doi.org/10.1016/0016-7037(95)00038-2.

Wittmaack, K., Keck, L., 2004. Thermodesorption of aerosol matter on multiple filters of different materials for a more detailed evaluation of sampling artifacts. Atmos. Environ. 8, 5205-5215. https://doi.org/10.1016/j.atmosenv.2004.05.047.

Xu, G., Gao, Y., Lin, Q., Li, W., Chen, L., 2013. Characteristics of water-soluble inorganic and organic ions in aerosols over the Southern Ocean and coastal East Antarctica during austral summer. J. Geophys. Res. Atmos. 118 (13), 303-313. https://doi.org/ 10.1002/2013JD019496.

Xu, H., Bi, X.H., Zheng, W.W., Wu, J.H., Feng, Y.C., 2015. Particulate matter mass and chemical component concentrations over four Chinese cities along the western Pacific coast. Environ. Sci. Pollut. Res. 22, 1940-1953. https://doi.org/10.1007/ s11356-014-3630-0.

Yan, P., Zhang, R., Huan, N., Zhou, X., Zhang, Y., Zhou, H., Zhang, L., 2012. Characteristics of aerosols and mass closure study at two WMO GAW regional background stations in eastern China. Atmos. Environ. 60, 121-131. https://doi.org/ 10.1016/j.atmosenv.2012.05.050.

Zhao, M., Zhang, Y., Ma, W., Fu, Q., Yang, X., Li, C., Zhou, B., Yu, Q., Chen, L., 2013. Characteristics and ship traffic source identification of air pollutants in China's largest port. Atmos. Environ. 64, 277-286. https://doi.org/10.1016/j. atmosenv.2012.10.007.

Đuričić-Milanković, J., Anđelković, I., Pantelić, A., Petrović, S., Gambaro, A., Đorđević, D., 2018. Size-segregated trace elements in continental suburban aerosols: seasonal variation and estimation of local, regional, and remote emission sources. Environ. Monit. Assess. 190, 615. https://doi.org/10.1007/s10661-018-6962-2. 